\title{
EL ESTADO Y EL ARBITRAJE: PRIMERA APROXIMACIÓN
}

\author{
Guido Santiago Tawil* e \\ Ignacio J. Minorini Lima**
}

\section{LA CRECIENTE IMPORTANCIA DEL ARBITRAJE COMO MÉTODO DE RESOLUCIÓN DE CONFLICTOS EN QUE EL ESTADO ES PARTE}

El incremento incesante del comercio internacional y los procesos de integración regional han llevado a una creciente utilización del arbitraje como método alternativo para la resolución de conflictos.

Las ventajas del arbitraje han sido destacadas frecuentemente por la doctrina y se han visto plasmadas en su mayor aceptación en el ámbito de las relaciones contractuales. La posibilidad de constituir tribunales con conocimiento especializado en las materias en debate, la mayor celeridad, economía, informalidad e inmediatez del procedimiento y la confidencialidad de las actuaciones son algunas de las razones por las cuales el arbitraje ha experimentado un crecimiento excepcional ${ }^{1}$.

* Catedrático de Derecho Administrativo de la Universidad de Buenos Aires (UBA). Presidente del Comité de Arbitraje de la IBA. Socio, M. \& M. Bomchil, Buenos Aires.

** Profesor Asistente de Derecho Administrativo de la UBA. Asociado, M. \& M. Bomchil, Buenos Aires.

1. No obstante ello, el arbitraje no constituye por cierto una panacea. Se han señalado como desventajas del arbitraje que (i) el riesgo de conflictos de interés es mayor en el caso de árbitros privados que en el de los tribunales de justicia; (ii) si su redacción no es precisa, las cláusulas arbitrales pueden dar origen a incidencias dilatorias con la consecuente pérdida de tiempo y dinero; (iii) alguna doctrína y legislación nacional perciben al arbitraje como un medio concebido para favorecer los intereses comerciales del mundo occidental desarrollado; (iv) la flexibilidad e informalidad puede ir en desmedro del buen orden del procedimiento, permitiendo mayores incidencias entre las partes con potencial efecto disruptivo sobre el arbitraje; (v) la necesidad de que las partes presten cierta colaboración para constituir el tribunal, acordar cuestiones de procedimiento, celebrar audiencias, etc., brinda oportunidades adicionales para que el lítigante malicioso obstaculice el procedimiento; (vi) si bien constituye un procedimiento relativamente más eficiente que los tribunales judiciales, su conveniencia en términos económicos debe ser analizada en cada caso, a fin de determinar si se justifica afrontar los costos derivados de los honorarios de los árbitros y de las instituciones de arbitraje (en el caso de arbi- 
Si bien la lentitud que se observa en los procesos judiciales no es, por cierto, un problema exclusivamente local, en nuestro país presenta aristas preocupantes ${ }^{2}$. Un estudio efectuado en el año 1998 por el Foro de Estudios sobre la Administración de Justicia (FORES) señalaba que el desfasaje existente entre el ingreso y egreso de causas en los juzgados de la Capital Federal ascendía al $40 \% 3$.

Una muestra de causas iniciadas en 1999 en el fuero comercial de la Capital Federal evidenciaba que tan sólo el 54\% de ellas había concluido en el lapso de cuatro años ${ }^{4}$. Más grave aún resulta la situación del fuero contencioso-administrativo federal. De acuerdo con un muestreo efectuado en el año 2003 por la Dirección Nacional de Auditoría de la Procuración del Tesoro de la Nación, obtener una sentencia de primera instancia en procesos de conocimiento en los que el Estado es parte y requieren apertura a prueba lleva alrededor de seis años y un mes 5 . Si a eso se le suma el tiempo que normalmente demandan los procesos de apelación a Cámara y la eventual intervención de la Corte por

trajes instinucionales) Ver Bom, Gary B., "International Commercial Arbitration", Transnational Publishers y Kluwer Law International, $2^{\circ}$ edición, La Haya, 2001, pp. 7-11. De acuerdo con un relevamiento efecruado por Julio César Rivera ("Arbitraje y poder judicial. Los prejuicios de los jueces respecto del arbitraje", Revista Internacional de Arbitraje, julio-diciembre 2006, p. 193 y siguientes), los jueces atgentinos encuentran como objeciones más comunes al arbitraje que éste "a) Es una moda. b) Es una 'privatización' de la justicia. c) Es un medio de opresión de las grandes empresas sobre las compañias de los paises emergentes. d) Es un modo de eludir la aplicación de la legislación estatal imperativa $\rightarrow$ de orden público- e) Los árbitros no son reaimente independientes de las partes. f) La confidencialidad atenta contra la transparencia del sistema y crea dificultades para conocer la 'jurisprudencia'. g) En el arbitraje doméstico no hay razones que justifiquen reemplazar al juez por tu tercero e implica desconfianza en los jueces. h) No siempre el procedimiento es tan barato ni simple".

2. FIEL, "La reforma del Poder Judicial en la Argentina", Buenos Aires, 1996. Sobre este tema, ver Tawil, Guido Santiago, "Advocacy in International Commercial Arbitration: Argentina", en Bishop, Doak (editor), "The Art of Advocacy in International Arbitration", Juris Publishing, Nueva York, 2004, pp. 358-360.

3. De acuerdio con el referido estudio, por año judicial se resuelven aproximadamente el $60 \%$ de las causas que ingresan (FORES, "Justicia \& Desarrollo Económico", Buenos Aires, 1999, p. 149, disponible en http:/www.foresjusticia.org.ar/investigaciones/JusticiaCEA/S2cap2.pdf (última visita: 31 de julio de 2006)).

4. FORES, "La gestión del fuero comercial. Análisis y propuestas", Buenos Aires, 2004, p. 74.

5. Rosatti, Horacio D., "Los tratados bilaterales de inversión, el arbitraje internacional obligatorio y el sistema constitucional argentino", La Ley 2003-F, 1283. A ello se le deben sumar los tiempos que insume el agotamiento de la instancia administrativa, por via recursiva o reclamativa dependiendo de la naturaleza de la pretensión. 
vía ordinaria o extraordinaria, bien puede suponerse que -más allá de los procedimientos previos a la interposición de la acción ${ }^{6}$ y posteriores de ejecución- un proceso judicial en el que el Estado sea parte difícilmente demande en la Argentina menos de diez años.

La excesiva lentitud de los procedimientos se traduce en elevados costos de transacción para la sociedad y la pérdida de inmediatez del juez con el expediente-como consecuencia de la congestión de las causas en trámite- potencia la posibilidad del error judicial 7 . En este contexto, el arbitraje se ha constituido en una alternativa interesante para superar tales escollos, reduciendo en alguna medida los costos transaccionales.

Si las razones señaladas han coadyuvado al auge creciente del arbitraje en el ámbito local, motivos adicionales favorecen su elección como medio de resolución de controversias en los conflictos de naturaleza internacional ${ }^{8}$.

6. En los juicios contra el Estado, el ondenamiento juridico argentino (ley 19.549) exige al litigante agotar previamente la via recursiva o reclamativa -excepción hecha del caso en que se encuentre exento de eflo- como presupuesto ineludible a fin de que el juez dé curso a la acción instaurada. Dependiendo del caso, obtener un pronunciamiento efectivo por parte de la Administración respecto de los recursos administrativos o reclamos interpuestos puede insumir varios años.

7. FORES, "Justicia \& Desarrollo ...", ob. cit. en nota 3, p. 161.

8. Teniendo en cuenta los diversos modos o circunstancias en que se puede desenvoiver un arbitraje, se han elaborado clasificaciones que se asientan en las diferentes variantes que ellos pueden presentar (Cajvano, Roque J., "Arbitraje", Ad-Hoc, $2^{\circ}$ edición, Buenos Ajres, 2000, p. 67). Entre ellas, cabe mencionar aquéllas que đistinguen entre el arbitraje voluntario y forzoso, ad-hoc e institucional, por árbjtros de derecho o anjugables componedores, y nacional e internacional. Gordillo señala con acierto que no existe una posición pacífica en la legislación ni en doctrina sobre los elementos que otorgan càrácter internacional a un arbitraje (Gordillo, Agustín, "Tratado de Derecho Administrativo", II, Fundación de Derecho Administrativo, $8^{\circ}$ edición, Buenos Aires, 2006, p. XVIIJ-8). La sede del tribunal, el lugar en que se pronuncia el laudo, la nacionalidad o domicilio de las partes o de los árbitros, la ley aplicable al procedimiento y al fondo de la controversia, el lugar de celebración y ejecución del contrato, la sede de la institución arbitral, el lugar en que el laudo será ejecutado, entre otros criterios, se han propuesto alternativa o concurrentemente como factores determinantes (bid;; Caivano, "Atbitraje", ob. cit. en nota 8, pp. 86-87; Gaillard, Emmanue! y Savage, John (editores), "Fouchard Gajllard Goldman on International Cormmercial Arbitration", Kluwer Law International, La Haya, 1999, p. 45 y siguientes). Al respecto, la ley modelo UNCITRAL sobre arbitraje comercial internacional brinda una importante guja en la materia. La Comisión de las Naciones Unidas para el Derecho Mercantit Internacional (CNUDMI o UNCITRAL conforme a su sigla en inglés) elaboró dicha ley modelo como instrumento de ammonización y perfeccionamiento, recomendando a los Estados adaptar sus leyes de arbitraje ateniéndose en la mayor medida posible aI modelo propuesto. Ver "Nota explicativa de la Secretaria de la CNUDMI sobre la ley modelo de la CNUDMI sobre arbitraje comercial internacional", disponible en http://www.uncitral.org/pdf/spanish/texts/arbitcatiol/mlab/ml-ab-s.pdf (última visita: 12 de agosto de 2006). Teniendo en cuenta que la ley modelo tiene 
Cuando las partes de una transacción son de distinta nacionalidad es frecuente observar cierta reticencia en alguna de ellas a someterse a los tribunales del país de su contraparte. El arbitraje aparece allí como un foro apto para superar la desconfianza natural hacia las jurisdicciones estatales. Permite, además, adoptar reglas que combinen armónicamente las diversas culturas jurídicas involucradas (common law, derecho continental europeo, etc.). En este sentido, más allá de la mayor influencia del derecho continental europeo en ámbitos como el de la Cámara de Comercio Internacional (CCI) o del derecho anglosajón en la London Court of International Arbitration (LCIA) las reglas de las principales instituciones de arbitraje han intentado plasmar en sus procedimientos principios universales.

En las últimas décadas se han reducido en forma considerable las materias no arbitrables, observándose una creciente aceptación del arbitraje en ámbitos tales como el de los recursos naturales, las inversiones extranjeras y la propiedad intelectual ${ }^{9}$. A este respecto, no sólo se advierte una expansión de las materias susceptibles de ser sometidas a arbitraje, sino también una mayor apertura en cuanto a la admisión de quienes pueden ser parte en el procedimiento.

por objeto uniformar los procesos arbitrales y satisfacer las necesidades de la práctica del arbitraje comercial internacional, sus criterios deben evaluarse con particular detenimiento y, en la medida en que lo permita la legislación local vigenle, interpsetar esta úllima en forma armónica con aquélla. De acuerdo con las pautas dispuestas por ella (artículo 1, inciso 3), un arbitraje será internacional si (a) al momento de la celebración del acuerdo arbitral, las partes tiene sus estabiecimientos en Estados diferentes o (b) alguno de los siguientes lugares se encuentra situado fuera del Estado en el que las partes tienen sus establecimientos: (i) el lugar del arbitraje, si esste se ha determinado en el acuerdo de arbitraje o con arreglo al acuerdo de arbitraje; (ii) el lugar de cumplimiento de una parte sustancial de las obligaciones de la relación comercial o el lugar que tenga una relación más estrecha con el objeto del litigio; o (c) las partes han convenido expresamente que la cuestión objelo del acuerdo arbitral está relacionada con más de un Estado. Por su parte, el Convenio Europeo sobre Arbitraje Comercial Internacional de 1961 adopta como factor determinante para definir el acuerdo de arbitraje como intemacional que éste haya sido “... concertados entre personas fisicas o juridicas que tengan, en el momento de estipulur un acuerdo o compromiso de este tipo, su residencia habitual o su domicilio o sede social en Estados contratantes diferentes".

9. Ver, asi, el prólogo de Horacio A. Grigera Naón al libro de Adriana N. Pucci, "Arbitraje en los países del MERCOSUR", Ad-Hoc, Buenos Aires, 1997 y Grigera Naón, Horacio A., "Arbitraje comercial internacional en el mundo actual", J.A. 1996-III, p. 701. 
Así, las legislaciones nacionales han previsto en forma creciente que los Estados puedan comprometer en arbitraje no ya únicamente conflictos suscitados con otros Estados -tradicionalmente regidos por el derecho internacional público- sino también controversias con particulares aún en supuestos relacionados con actividades de índole no comercial. Esa tendencia permitió advertir el progresivo abandono de la doctrina Calvo por parte de algunos de sus principales impulsores e hizo suponer en algún momento que ella había quedado definitivamente superada $^{10}$.

Así parecían demostrarlo la suscripción de tratados de integración como el NAFTA y el Energy Charter Treaty, la celebración de tratados bilaterales de protección y promoción de inversiones incluyendo mecanismos de resolución de disputas entre Estados y entre éstos y nacionales de otros Estados y del Convenio Internacional de Arreglo de Diferencias Relativas a Inversiones -conocido también como el Convenio CIADI o la Convención de Washington de $1965^{11}$.

La creciente utilización de tales mecanismos ha generado, sin embargo, una reacción adversa al arbitraje, visible particularmente en aquellos países que se han visto demandados en forma creciente. Ciertas posiciones esbozadas recientemente por los Estados Unidos, Argentina y otros países a fin de limitar la utilización del arbitraje son claros ejemplos de esta corriente.

10. Como ha señalado el primero de los autores en otra oportunidad ("Los tratados de protección y promoción recíproca de inversiones. La responsabilidad del Estado y el arbitraje internacional", La Ley 2000-D, p. (106), la llamada doctrina Calvo se erigia en una de las principales barreras al sometimiento del Estado al arbitraje con particulares en el ámbito intemacional. La denominación se debe a quien fuera su inspirador, el diplomático e internacionalista argentino Carlos Calvo quien, en sintesis, postulaba que en función del principio de igualdad de los Estados, los nacionales de otros paises carecian de derechos y privilegios especiales y las controversias relativas a reclamos de esos extranjeros contra los Estados receptores debian dirimirse exclussivamente de conformidad con las leyes de cstos últimos y ante sus tribunales.

11. El Convenio CIADI instituyó el Centro Internacional de Arreglo de Difercncias Rclativas a Inversiones, con el objeto de proporcionar un foro para la resolución de conflictos cn un marco de equilibrio entre los intereses y las necesidades de las partes involucradas, con el propósito particular de "despolitizar" el arreglo de las diferencias en materia de inversiones. Ver, al respecto, Tawil, "Los tratados de protección ...", ob. cit nota 10, p. 1106 y siguientes. 
En el caso de los Estados Unidos ${ }^{12}$ esa posición se ha visto plasmada en (i) las presentaciones efectuadas por esa nación en procedimientos arbitrales iniciados por sus propios nacionales contra Canadá o México bajo el NAFTA, en las cuales -de conformidad con su artículo 1128- sostuvo interpretaciones restrictivas de las protecciones brindadas por ese tratado13; (ii) la sanción de la Trade Act en el año 200214; (iii) el modelo de tratado bilateral de inversión del año 2004 que, comparado con el de 1994 que lo precediera, si bien no excluye el recurso al arbitraje, restringe los derechos reconocidos a los inversores extranjeros ${ }^{15}$; y (iv) los tratados multilaterales y bilaterales suscriptos a la luz de dicho modelo (entre otros, el CAFTA-DR y los tratados bilaterales con Australia y Uruguay).

Por su parte, a pesar de haber anunciado el abandono de la doctrina Calvo al alentar la suscripción de más de 50 tratados de protección y promoción recíproca de inversiones a principios de la década del 90, la Argentina ha desempolvado nuevamente argumentos estrechamente vinculados con ella ${ }^{16}$ tanto en los

12. Desde el año 1998 hasta el presente, Estados Unidos ha enfrentado más de 15 arbitrajes internacionales iniciados por inversores mexicanos o canadienses en el marco del NAFTA.

13. Por ejemplo, "Pope \& Talbot Inc. v. Canadä" y "Metalclad Corporation v. México".

14. En cuanto ella dispone que "... el principal objetivo de negociación de los Estudos Unidos en relación con la inversión exiranjera es reducir o eliminar las artificiales o distorsivas barreras comerciales para la inversión extranjera, a la vez de asegurar que los inversores extranjeros en los Estados Unidos no les sean concedidos mayores derechos sustantivos con respecto a la protecciones de las inversiones que los inversores estadotmidenses en los Estados Unidos ..." ("... the principat negotiating objectives of the United States regarding foreign investment are to reduce or eliminate artificial or trade-distorting barriers to foreign investment, while ensuring that foreign investors in the United States are not accorded greater substantive rights with respect to investment protections than United States investors in the United States...").

15. Asi, por ejemplo, en materia de expropiación el nuevo modelo de tratado dispone que, excepto en raras circunstancias, medidas regulatorias de carácter no discriminatorio adoptadas por una parte y diseñadas y aplicadas para proteger legitimos fines de bienestar pủblico, tales como medioambiente, salubridad y seguridad públicas no constituyen expropiaciones indirectas. Ver, Anexo B, párrafo 4(b) del modelo de tratado bilateral de inversión del año 2004 de los Estados Unidos. Asimismo, en materia de trato justo y equitativo, el modelo de 2004, a diferencia de su predecesor de 1994, testringe el concepto al mírimo estándar de trato exigido por el derecho internacional consuetudinario. Ver articulo 5(1) del modelo de tratado bilateral de inversión del año 2004 de los Estados Unidos.

16. La naturaleza de las objeciones efectuadas a la jurisdicción y competencia de los tribunales arbitrales constinidos bajo las reglas del CIADI, la pretensión de aplicar la ley argentina en la interpretación de los estándares previstos en los tratados, los numerosos artículos publicados en revistas juridicas reivindicando el foro local como ámbito exclusivo para la resolución de esas controversias y los diversos proyectos de leyes proponiendo denunciar el Convenio CIADI y los tratados bilaterales de inversión, limitar la fuerza ejecutoria de los laudos o condicionar la inversión extranjera son sólo algunos ejemplos de esta tendencia. 
procesos arbitrales en los que es parte como en declaraciones periodísticas e iniciativas legislativas ${ }^{17}$.

Sin embargo, más allá de ciertas posiciones adversas al sometimiento del Estado al arbitraje y reacciones visibles recientemente, el arbitraje con partes estatales ejerce hoy un importante rol en el orden económico internacional. Stubsisten, por cierto, diferencias relevantes entre los arbitrajes en que un Estado es parte $y$ aquél que atañe únicamente a partes privadas. Cuestiones tales como la arbitrabilidad subjetiva, las restricciones impuestas por las legislaciones nacionales, la revisión de los laudos y la inmunidad de ejecución son sólo algunas de las que mayor relevancia han asumido cuando una de las partes de la controversia es una persona estatal.

\section{Cuestiones que Plantea la participación DEL ESTADO EN ARBITRAJE}

\section{II.1 La llamada arbitrabilidad subjetiva y el limitado alcance del derecho interno}

A fin de determinar la validez de una cláusula arbitral no solo debe verificarse que las partes hayan prestado válidamente su consentimiento sino también que él haya sido otorgado dentro de los límites establecidos por el ordenamiento jurídico ${ }^{18}$. El cumplimiento de este requisito, conocido como arbitrabilidad,

17. Diversos proyectos de ley se han presentado recientemente en el Congreso inspirados en la doctrina Calvo. Así, por ejemplo, la iniciativa legislativa de la senadora Mabel Müller (Expte. 532/05) declara inoponibles a la República Argentina aquellos laudos arbitrales que no puedan ser recurridos ante la Corte Suprema y prohibe al Sector Público Nacional prorrogar jurisdicción a favor de tribunales arbitrales para la resolución de conflictos patrimoniales en los que no se prevea el derecho a recurrir los laudos ante la Corte Suptema. Otras iniciativas contienten disposiciones similares, reivindicando la jurisdicción argentina. Ver, entre otros, los proyectos de ley (i) de los senadores Ricardo Gómez Diez y Pedro Salvatori (Expte. 2577/05, habilitando a los jueces argentinos a revisar todos los laudos arbitrales previo a su ejecución); (ii) del diputado Luis F. Zamora (Expte. 6737-D-05, derogando los tratados bilaterales de inversión suscriptos por la Argentina y el Convenio CIADI) y (iii) de los diputados Noet Breard, Luis Borsani, Gustavo Cusinato, Federico Storani, Margarita Stolbizer y Leopoldo Morean, entre otros (Expte. 0285-D-05, ordenando al Estado Nacional invocar en todo proceso arbjtral del que sea parte que los laudos no serán definitivos, queđando sujetos a revisión por la justicja argentina).

18. Gaillard y Savage (editores), "Fouchard Gaillard Goldman ...", ob. cit. en nota 8, p. 312. 
se traduce en la exigencia, por un lado, de que el acuerdo arbitral se vincule con materias susceptibles de ser dirimidas en arbitraje y, por otro, que las partes se encuentren legalmente habilitadas para comprometerse en arbitraje ${ }^{19}$.

Vinculada con la protección al interés general, el término se relạciona en su faz subjetiva con la aptitud de las entidades estatales para someterse a arbitraje ${ }^{20}$.

Efectuando un paralelo con conceptos propios del derecho administrativo y dada la diversa categoría de intereses a los que se dirigen cada uno de estos conceptos ${ }^{21}$, la arbitrabilidad subjetiva se encontraría más emparentada con las cuestiones de competencia que con las de capacidad ${ }^{22}$.

Desde esa óptica, la ausencia de arbitrabilidad subjetiva es en general explicada en términos de incompetencia y no de incapacidad.

La incompetencia del Estado para comprometer en árbitros se presenta así como una restricción al arbitraje por razones de interés general u orden público interno. Prohibir o restringir el acceso al arbitraje limitando las materias susceptibles de someterse a ese mecanismo (arbitrabilidad objetiva) o mediante el establecimiento de trabas a la competencia de los organos estatales (arbitrabilidad subjetiva) constituyen dos caras de la misma moneda, tendientes a limitar la vía arbitral por razones de interés general y, por ello, reclaman un tratamiento conjunto.

19. Ibid.

20. Hanotiau, Bernard, "The Law apticable to Arbitrability", ICCA Congress scrics No 9, Paris, 1999, p. 146.

21. Gaillard y Savage (editores), "Fouchard Gaillard Goldman ...", ob. cit. en nota 8, p. 317.

22. Salcedo Castro, Myriam, "La arbitrabilidad subjetiva: la capacidad de las entidades públicas para concluir contratos de arbitraje", en Silva Romero, Eduardo (Director Académico) y Mantilla Espinosa, Fabricio (Coord́inador Académico), "El contrato de arbitraje", Legis, Bogotá, 2005, pp. 119-120; Rosa Moreno, Juan, "El arbitraje administrativo", MeGraw-Hill, Madrid, 1998, p. 116. Nos referimos en el caso a la incapacidad de hecho. En relación con ta incapacidad de derecho, debe verse en elta, asimismo, una cuestión de arbitrabilidad subjetiva en tanto tiene por objeto la protección del interés general. 
Pese a las diferencias señaladas, la utilidad práctica del término arbitrabilidad subjetiva ha sido cuestionada por considerarse que no resulta posible distinguirla del concepto de capacidad. Así, se ha afirmado que más allá de la terminología a utilizar, la cuestión central radica en determinar las restricciones que puedan existir para que las entidades estatales comprometan en árbitros ${ }^{23}$.

Sin perjuicio del trasfondo semántico del debate ante la similitud conceptual existente entre la arbitrabilidad subjetiva y la capacidad de derecho, la distincion presenta consecuencias prácticas concretas en el ámbito del arbitraje internacional ${ }^{24}$. La noción amplia de arbitrabilidad permitiría despejar la incertidumbre que se presenta en relación con la ley aplicable a la capacidad de las personas en el ámbito del derecho internacional privado, aplicando en su lugar un régimen uniforme a la validez de la cláusula arbitral tanto en su faz objetiva como subjetiva.

Silva Romero explica ello en los siguientes términos:

"... [si] se incluye que se está en presencia de un problema de capacidad, el derecho aplicable a la cuestión será el de la nacionalidad de la parte estatal, y la posible conclusión será que la parte estatal era o es incapaz de contratar pactos arbitrales. $\mathrm{Si}$, por el contrario, se concluye que se trata de un problema de arbitrabilidad, el derecho aplicable será el que se le aplica al pacto arbitral, esto es, en la mayoría de los países, el derecho de la sede del arbitraje internacional o lex arbitri (de acuerdo, por lo menos, con lo dispuesto en el artículo $\mathrm{V}$ de la Convención de Nueva York de 1958 relativa al reconocimiento y la ejecución de laudos arbitrales extranjeros). Si la sede del arbitraje no está localizada en el país de la parte estatal, lo que ocurre con frecuencia, la conclusión puede ser que la entidad estatal sí era o es capaz de dar su consentimiento con respecto a pactos arbitrales" 25 .

23. Redfern, Alan y Hunter, Martin, "Law and practice of international commercial arbitration", Sweet \& Maxwell, Londres, 1999, p. 147.

24. Silva Romero, Eduardo, "El arbitraje examinado a la luz del derecho de las obligaciones" en Silva Romero, Eduatdo (Director Académico) y Mantilla Espinosa, Fabricio (Coordinador Académicico), "El Contrato de Arbitraje", Legis, Bogotá, 2005, p. Xx.

25. lbid. 
Si como ocurre en forma creciente en este campo 26 , se admite, además, una amplia autonomía de la cláusula arbitral respecto de las disposiciones de las legislaciones nacionales 27 , la cuestión de la arbitrabilidad subjetiva presenta una utilidad jurídica aún mayor. En efecto, de considerarse que la aptitud de personas estatales de comprometer en árbitros hace a la capacidad de esas personas, las eventuales controversias que ello pudiera generar deberán resolverse, por lo general, en los países de tradición continental europea a la luz de la ley de la nacionalidad de las partes y en los países del common law en función de la ley del domicilio. En cambio, de acogerse la teoría de la arbitrabilidad subjetiva, la cuestión deberá dilucidarse en función de lo que denominan las normas sustantivas del derecho internacional por resultar esa la ley aplicable al pacto arbitral y no ya la de la sede del arbitraje internacional ${ }^{28}$.

A partir de la decisión emitida en un arbitraje sustanciado bajo el reglamento de la CCI en año $1971^{29}$ se ha elaborado en el

26. Ver, asi, Gaillard y Savage (editores), "Fouchard Gaillard Goldman ...", ob. cit. en nota 8, pp. 235236; Hanotiau, "The Law aplicable ..." ob. cit. en nota 20 , p. 148.

27. En esta posición, la cuestión de la validez de la cláusula compromisoria (arbitrabilidad objetiva y subjetiva) se desliga de las normas de cualquicr derccho nacional para someterse únicamente a los requerimientos del orden público internacional. Ver, asi, Gaillard y Savage (editores), "Fouchard Gaillard Goldman ...", $o b$. cit. en nota 8, p. 218 y siguicntes. Eșta posición se vincula en cierta medida con la idea de la "desnacionalización" del arbitraje internacional, que se presenta en teoría como atractiva al eliminar la incertidumbre que suscita la aplicación de los principios de derecho internacional privado. Sin embargo, se ha criticado que ella se aparta de posiciones arzaigadas en el dcrecho internacional privado y el derecho procesal intcrnacional y que, en la práctica, su aplicación sólo es posible en la medida que el derecho local (lex arbitri) la admita. Ver, asi, Redfern y Hunter, "Law and practice ...", ob. cit. en nota 23, p. 91; Sandrock, Otto, "To continuc nationalizing or to dc-nationalize? That is now the question in international arbitration", 12 Am. Rey. Int'1 Arb. 301. Asimismo, la teoría de la "desnacionalización" origina incertidumbres sobre las reglas que se aplicarían al arbitraje internacional ante las vaguedades y ambigüedades que presenta en la práctica la lex mercatoria. Ver Delaume, Georges R., "Comparative analysis as a basis of law in state contracts: the myth of the lex mercatoria", 63 Tul. L. Rev. 575).

28. Gaillard y Savage (editores), "Fouchard Gaillard Goldman ...", ob. cit. en nota 8, pp. 316-318.

29. Compañia italiana v. entidad estatal africanta, Caso CCI N ${ }^{\circ} 1939$, referenciado en Salini Costruttori S.P.A. (Italia) v. The Federal Democratic Republic of Ethiopia, Addis Ababa Water and Sewerage Authority, (Caso CCI N"10.623/AER/ACS), laudo sobre suspensión del procedimicnto y jurisdicción (7 de diciembre de 2001), Revista Latinoamericana de Mediación y Arbitraje, Vol. III, $\mathrm{N}^{\circ} 2$ (2003), p. 159. Por razones de confidencialidad, en ciertas decisiones arbitrales que se hacen públicas no sc identifican con precisión las partes intervinientes sino únicamente ciertos elementos mínimos a los efectos de distinguir la decisión. 
ámbito del arbitraje internacional el principio -inspirado en la jurisprudencia francesa- de que los Estados y entes estatales no pueden alegar las disposiciones restrictivas de su propio derecho interno para cuestionar la validez de una cláusula compromisoria consentida sin reservas ${ }^{30}$. No tratándose el sometimiento del Estado a arbitraje de una cuestión de capacidad, sino de arbitrabilidad, la ley del Estado parte resulta inaplicable, en tanto la materia se rige por las normas sustantivas del derecho internacional que ratifican la arbitrabilidad del Estado y consideran contrario a la buena fe que éste pretenda desconocer sus compromisos previos sobre la base de normas que él mismo dictó y que, por consiguiente, no son heterónomas a su respecto ${ }^{31}$.

La jurisprudencia francesa y la legislación suiza han incorporado esa regla ${ }^{32}$, compartida con limitaciones por el Convenio Europeo sobre Arbitraje Comercial Internacional de $1961^{33}$. Así, el artículo 177(2) de la ley federal suiza de derecho internacional privado prescribe que "si tina parte del acuerdo de arbitraje es un Estado, una empresa controlada por el Estado o una organización de propiedad del Estado, no puede fundarse en su propia ley a fin de cuestionar su capacidad para ser parte en un arbitraje o la arbitrabilidad de una disputa comprendida en el acuerdo de arbitraje".

30. Gaillard y Savage (editores), "Fouchard Gaillard Goldman ...", ob. cit. en nota 8, p. 322; Paulsson, Jan, "May a State Invoke its International Law to Repudiate Consent to International Commercial Arbitration? Reflections On the Benteler v. Belgium Preliminary Award", Arbitration International, Vol. 2, $\mathrm{N}^{\circ} 2$, p. 90; Hanotian, "The Law aplicable ..." ob. cit. en nota 20, p. 151.

31. Similar fundamento dio origen a una regla básica en materia de derecho de los tratados, equivalente -salvando las diferencias- al principio aqui expuesto. El artículo 27 de la Convención de Viena sobre el Derecho de los Tratados, aprobada en nuestro país por ley 19.865 dispone que "una parte no podró invocar las disposiciones de su derecho interno como justificación del incumplimiento de un tratado ...".

32. Silva Romero, Eduardo, "ICC Arbitration and State Contracts", ICC International Court of Arbitration Bulletin Vol. 13/No. 1, 2002, p. 38; Gaillard y Savage (editores), "Fonchard Gaillard Goldman ...", oh. cit. en nota 8, pp. 318-322; Hanotiau, "The Law aplicable ..." ob. cit. en nota 20, pp. $148-152$.

33. El artículo II de este convento establece así: " 1 . En los casos previstos en el articulo I, párrafo I, del presente Convenio, las personas morales consideradas por la ley a ellas aplicable como "personas morales de derecho público" estarán factultadas para concertar válidamente acuerdos o compromisos arbitrales. 2. Al firmar o al ratificar el presente Convenio o al adherirse al mismo, todo Estado contratante podrá declarar que limita dicha facultad segun las condiciones concretadas en su declaración". 
En función de esta regla, en aquellos supuestos en que un Estado parte en un arbitraje alega la nulidad de la cláusula compromisoria en función de prohibiciones o restricciones existentes en su derecho interno para comprometer en árbitros, los tribunales arbitrales internacionales han desestimado, en general, esta clase de objeciones. A este respecto, frecuente es la cita del laudo dictado en el caso Framatome ${ }^{34}$.

Este relevante principio encuentra sustento, asimismo, en el orden público internacional ${ }^{35}$ y el principio de la buena $\mathrm{fe}^{36}$, de plena aplicación tanto en el derecho administrativo ${ }^{37}$ como

34. Ver Lehman, Matthias, "A plea for a transnational approach to arbitrability in arbitral practice", 42 Colum. J. Transnat' L. 753, p. 761. Como señaló el referido tribunal arbitral "... sería superftuo insistir en que existe un principio general que en la actualidad es universalmenie reconocido en las relaciones entre estados asi como en las relaciones internacionales entre entidades privadas (considerado como un principio de orden público internacional, un uso del comercio internacional o un principio reconocido por el derecho internacional público, el derecho internacional arbitral o la lex mercatoria), en virtud del cual el estado irani se hallaria a todo evento aún si asi lo hubiera pretendido, que no es el caso- impedido de renegar de un acuerdo de arbitraje celebrado por el propio estado o, previamente, por una entidad puiblica como AEOr. El texto citado en el otiginal en francés reza: "Il est superfu d'ajouter qu'un principe général, aujourd 'hui universellement reconnu tant dans les rapports interétatiques que dans les rapports internationaux privés (que ce principe soit considéré comme d'ordre public international, comme appartenant aux usages di commerce international ou aux principes reconnus tant par le droit des gens que par le droit de l'arbitrage international ou la "lex mercatoria") interdirait de toute façon à I'Etat iranien - même s'il en avât eu l'intention, ce qui $n$ 'est pas le cas - de renier l'engagement d'arbitrage qu'il aurait souscrit lui-même ou qu' 'un organisme public comme l'AEOI aurait souscrit précédemment". Ver, caso CCI $\mathrm{N}^{\circ} 3896$, Framatome S.A. v. Alomic Energy Organization of Iran (AEOI), laudo sobre jurisdicción (30 de abril de 1982), 111 J.D.I. 58 (1984). Frecuente es la cita por parte de los tribunales constituidos bajo las reglas de la CCI de este principio a fin de desestimar las objeciones planteadas respecto de la validez de la cláusula arbitral por los estados o entes controlados demandados. Ver, al respeclo, Silva Romero, "ICC Arbitration ...", ob. cit. en nota 32, p. 39. La regla referida es también frecuentemente enunciada en arbitrajes ad-hoc. Ver, así, Gaillard y Savage (editores), "Fouchard Gaillard Goldman ...", $o b$. citt. en nota 8, p. 326 .

35. Si bien la teoria de la aplicación de las nơrnas sustantivas para establecer la arbitrabilidad subjetiva justifican cl principio enunciado, no nccesariamente debe adscribirse a dicha teoria a fin de aplicarlo. Sin lacer referencia a ella y aplicando la ley personal del Estado para establecer su capacidad para comprometer en árbitros, Lalive cxpresa que el orden público transnacional impediria que éste invoque su propia legíslación para desconocer un acuerdo de arbítraje libremente pactado. Ver Lalive, Picrrc, "Ordre public transnational (ou recllement international) et arbitrage international", Revue de l'Arbitrage 3 (1986), 329, p. 344.

36. Silva Romcro, "ICC Arbitration ...", ob. cit. en nota 32, p. 39; Gaillard y Savage (editores), "Fouchard Gaillard Goldman ...", ob. cit. en nota 8, pp. 325-329; Paulsson, "May a State Invoke its International Law ...", ob. cit. en nota 30, p. 90.

37. En tal sentido, nuestra Corte Suprema ha sostenido desde, por lo menos, 1871 que "la administración debe ser leal, franca y pública en sus actos" (Fallos: 10:203). En el campo del derecho comparado, ver González Pérez, Jesús, "El principio de la buena fe en el derecho adiministrativo", Civitas, Madrid, [983. 
internacional ${ }^{38}$. Tales principios y la prohibición del Estado de actuar contra sus propios actos - plasmada en el brocardo clásico "venire contra propium factum non valet"-impiden celebrar por un lado un acuerdo de arbitraje para luego alegar su nulidad en el procedimiento arbitral, en función de restricciones establecidas en su propio derecho ${ }^{39}$. Esa conducta implica, asimismo, una violación de los deberes básicos de información (disclosure) y colaboración que deben observarse en toda transacción, habida cuenta que, de hallarse el Estado impedido de celebrar acuerdos arbitrales, debería hacerlo saber a su contraparte ${ }^{40}$.

38. Ver, asi, González Campos, Julio D.; Sánchez Rodriguez, Luis I.; Sảenz de Santa Maria, Paz Andrés; "Curso de Derecho Internacional Público", Civitas, $2^{\circ}$ edición, Madrid, 2002, pp. 92-93, entre muchos otros.

39. En los casos de la Plataforma Continental del Mar del Norte, la Corte Internacional de Justicia señaló que "sólo la existencia de tuna situación de estoppel podria avalar las alegaciones de Dinamarca y los Paises Bajos -es decir, si la República Federal estuviera ahora impedida de rechazar la aplicación del régimen convencional, a causa de contuctas previas, declaraciones, etc. que no sóto evidenciaran de manera clara y consistente la aceptación de ese régimen, pero que también hubieran llevado a Dinamarca o los Paises Bajos, basándose en esa conducta, a modificar su posición en su detrimento o a sufrir algún perjuicio" ("Only the existence of a situation of estoppel could lend substance to the contention of Denmark and the Netherlands - i.e., if the Federat Republic were now precluded from denying the applicability of the conventional regime, by reason of past conduct, declarations, elc., which not only clearly and consistently evinced acceptance of that regime, but also had caused Denmark or the Netheriands, in reliance on such conduct, detrimentally to change position or suffer some prejudice"). Ver asi North Sea Continental Shelf Cases, ICJ Judgment of 20 February 1969, ICJ Reports (1969). Sin embargo, no existe uniformidad en la aplicación de la regla dej estoppel en derecho internacional ni existe una clara delimitación entre el concepto de estoppel y la doctrina de los actos propios en ese campo. De sostenerse que para la legítima invocación del estoppel se requiere que la conducta del Estado se encuentre autorizada -tal como sostienen algunos autores en el ámbito internacional- o que la conducta previa sea válida como afirma Mairal en relación con la doctrina de los actos propios en el derecho administrativo argentino (Mairal, Héctor A., "La doctrina de los propios actos y la administración pública", Depalma, Buenos Aires, 1988, pp. 6-7)- podrían suscitarse discusiones sobre si la regla que impicie al Estado invocar su propio derecho para desconocer una cláusula arbitral encuentra fundamento en aquellas doctrinas, toda vez que no podría afirmarse que quien celebra un acuerdo arbitral prohibido por la legislación nacional vigente se encuentra autorizado para ello o que dicha conducta sea válida. No obstante ello, la respuesta dependerá de la ley que se estime aplicable a la validez de la cláusula arbitral. De acogerse la teoría de la arbitrabilioad subjetiva regida por nomas sustantivas del derecho internacional, la discusión scria superada, en tanto no habría dudas sobre la validez de la conducta previa.

40. En el plano internacional, es regla establecida que el Estado debe conducirse "... de manera coherente, desprovista de ambigüedades y transparente en sus relaciones con el inversor extranjero, de manera que éste pueda conocer de manera anticipada, para planificar stus actividades y ajustar su conducta, no sólo las normas o reglanentaciones que regirán tales actividades, sino también las politicas perseguidas por tal normativa y las prácticas o directivas administrativas que les son relevantes. Un accionar del Estado ajustado a tales criterios es, pues, esperable, tanto en relación con las pattas de conducta, directivas o requerimientos impartidos, o de las resoluciones dictadas de conformidad con las mismas, cuanto con las razones y finalidades que las subyacen. El inversor extranjero también espera que el Estado receptor actuará de manera no contradictoria; es decir, entre otras cosas, sin revertir de manera arbitraria decisiones o aprobaciones anteriores o preexistentes emanadas del Estado en las que el inversor confió y basó la asunción de sus compromisos y la planifica- 
A pesar de la relevancia de esta regla, de su aplicación tanto por tribunales arbitrales constituidos bajo las reglas de la CCI como por ciertos tribunales locales ${ }^{41} \mathrm{y}$ de su recepción en legislaciones tales como la suiza, no resulta apropiado considerarla todavía como una práctica uniformemente aceptada, principio de la lex mercatoria o del orden público internacional ${ }^{42}$. Varias son las razones para ello.

En primer lugar, su admisión no es pacífica, subsistiendo opiniones que rechazan la distinción entre capacidad y arbitrabilidad subjetiva y propugnan una solución uniforme con fundamento en que las restricciones para que el Estado comprometa en árbitros deben determinarse en función de la ley local de ese Estado. En apoyo de esta posición, se suele sostener que si quien celebra un acuerdo de arbitraje en representación del Estado no se encuentra autorizado para ello no puede considerarse que aquél queda obligado por tal acuerdo ${ }^{43}$. De este modo, se asimila a la solución prevista en el campo del derecho administrativo para los supuestos de nulidad absoluta del acto por vicio en el elemento subjetivo ${ }^{44}$.

ción y puesta en marcha de su operación económica y comercial (...)". Ver, así, Técnicas Medioambientales Tecmed, S.A. v. Estados Unidos Mexicanos, (Caso CIADI N ARB(AF)/00/2), laudo, 29 de mayo de 2003, disponible en http//ta.law.uvic.ca/documents/Tecnicas-Spanish.ndf (última visita: 9 de agosto de 2006), párrafo 154. Asimismo, se ha dicho que la transparencia "... inchye la idea de que todo requerimiento legal pertinente a efecto de iniciar, completar $u$ operar exitosamente inversiones realizadas, o que se tenga intención de realizar al amparo del Tratado, deberian de ser de fácil conocimiento de todos los inversionistas afectados de la otra Parte. No debería de haber lugar a duda o incertidumbre en tales asuntos. Una vez que es del conocimiento de las autoridades del gobierno central de una Parte (cuja responsabilidad internacional en estos asuntos se identificó en la sección que precede) de que pudiera haber lugar para un malentendido o confusión a este respecto, es su deber asegurarse que la posición correcta se determine y exprese rápida y claramente para que los inversionistas puedan proceder con toda la apropiada prontitud y con la seguridad de que están actuando conforme a las leyes pertinentes ...". Ver Metalclad Corporation $v$. Estados Unidos Mexicanos (Caso $\mathrm{N}^{\circ}$ ARB(AF)/97/1), Jaudo, 30 de agosto de 2000, disponible en http:/ita.law.uyic.ca/documents/MetacladAward-Spanish.pdf (última visita: 9 de agosto de 2006), párafo 76.

41. Gaillard y Savage (editores), "Fouclzand Gaillard Goldman ...", ob. cit en nota 8, p. 322 y siguientes.

42. Silva Romero, Eduardo, "Requiem for the Rule of Article 177(2) of the Swiss Private International Law Act?", en Aksen, Gerald; Böckstiegel, Karl-Heinz; Mustill, Michael J.; Patocchi, Paolo Michele; Whitcsell, Anne Marie (editores), "Global Reflections on International Law, Commerce and Dispute Resolution", Cámara de Comercio Internacional, 2005, p. 825 y siguientes.

43. Rubino-Sammartano, Mauro, "International Arbitration. Law and Practice", KJuwer Law Internacional, $2^{\circ}$ edición, Países Bajos, pp. 200-201.

44. Ver, así, en la Argentina, lo dispuesto en los artículos 14, inc, b) y 17 de la ley 19.549. 
En segundo orden, no puede desconocerse que la arbitrabilidad subjetiva y la regla enunciada no han tenido mayor recepción en países tradicionalmente reticentes al arbitraje. Basta recordar, por ejemplo, que en el caso de los estados latinoamericanos, buena parte de sus legislaciones no admitían siquiera, hasta hace poco tiempo atrás, la potestad del tribunal arbitral de expedirse sobre su propia competencia (principio kompetenzkompetenz $)^{45}$.

Por último, se ha sugerido que la regla que prohibe la invocación de la legislación interna por parte de un Estado o entidad estatal para cuestionar la validez de una cláusula arbitral debería ser revisada a la luz de los principios de seguridad jurídica y buena $\mathrm{fe}^{46}$.

En esta línea, se ha sostenido que la lex mercatoria debe ser aplicada tanto al Estado y sus entidades como al contratante extranjero. Si bien los primeros cargarían con los deberes de información (disclosure), transparencia y colaboración, no es menos cierto que quien contrata con un Estado tendría la obligación de verificar que su contraparte se encuentra habilitada legalmente para comprometer en árbitros. La omisión de efectuar tal análisis colisionaría con el accionar exigible a un buen hombre de negocios, obstando a que pudiera posteriormente alegar su propia torpeza y pretender que el acuerdo arbitral sea tenido por válido ${ }^{47}$.

45. En lo que hace al principio de kompetenz-kompetenz, se observa una creciente tendencia a su aceptación a medida que, como ha ocurrido en Brasil, Chile, Colombia, Ecuador, México, Paraguay y Perú, los países de la región han regulado el arbitraje en legislaciones que toman como base la Ley Modelo de UNCITRAL, cuyo articulo 16(1) dispone: "El tribunal arbitral estará facultado para decidir acerca de su propia competencia, inchuso sobre las excepciones relativas a la existencia o a la validez del acuerdo de arbitraje. A ese efecto, una clátsula compromisoria que forme parte de un contrato se considerará como un acuerdo independiente de las demás estipulaciones del contrato. La decisión del tribunal arbitral de que el contrato es nulo no entrañará ipso jure la nulidad de la cláusula compromisoria".

46. Silva Romero, "Requiem for the Rule of Article $177(2)$...", ob. cit. en nota 42, p. 825 y sigutentes. El autor plantea dudas, asimismo, sobre la posibilidad de fundar la regla en el vago concepto de orden público internacional.

47. Ibid. 
Sin embargo, ¿hasta dónde puede exigirse a quien contrata con un Estado el verificar en forma autónoma la compatibilidad del accionar de dicho Estado con su orden jurídico interno? Si el accionar estatal no aparece como manifiestamente ilegítimo -entendiendo como tal a aquél detectable con un grado mínimo de diligencia y atención- ¿puede imputársele a su contratante culpa alguna en el acuerdo celebrado con quien actúa públicamente sin reproche y cumpliendo formas que aparentan su legalidad?

Asimismo, con la salvedad expresa del supuesto de dolo o connivencia, debe admitirse que en aquellos casos en que el Estado invoca posteriormente la ausencia de arbitrabilidad subjetiva ello se debe, en general, a un cambio de criterio (o, inclusive, ausencia de un criterio uniforme) o a un supuesto de torpeza de la propia parte estatal más que de su contraparte.

En este sentido, la diligencia exigible a un buen hombre de negocios no puede extenderse al punto que deba presumir la mala fe de un ente estatal o que pueda exigírsele un examen independiente de la legitimidad de todos y cada uno de los actos que celebre su contraparte. Más aún cuando las normas estatales no son uniformes o heterónomas respecto del propio Estado.

Aún cuando se aceptaran, por hipótesis, ciertas restricciones a la aplicación de la regla, ella mantendría vigencia prácticamente indiscutible en los supuestos de ilegitimidad sobreviviente. No podría admitirse así que con posterioridad a la celebración del acuerdo arbitral el Estado modificara su legislación y pretendiera fundar en ese cambio su objeción a la jurisdicción arbitral. Similar reproche cabría formular en aquellos casos donde si bien no se produce una modificación normativa, el Estado adopta un nuevo criterio de interpretación en desmedro de su práctica anterior.

Los principios de indivisibilidad del Estado en el plano internacional, información, buena fe y transparencia tornarían 106 Revista Ectuatoriana de Arbitraje 
aplicable semejante solución cualquiera fuera el órgano estatal que cuestionara posteriormente el sometimiento a arbitraje. La regla referida resultaría así aplicable aún cuando quien cuestiona el sometimiento a arbitraje sea otro poder estatal.

En Salini Costruttori S.P.A. v. Etiopía -caso tramitado bajo el reglamento de arbitraje de la CCI- los demandados recusaron a todos los miembros del tribunal arbitral en el marco de una incidencia respecto a la sede del arbitraje (Addis Ababa, Etiopía) y el lugar en que el Tribunal dispuso la celebración de las audiencias sobre jurisdicción y mérito (París). Ante el rechazo de la recusación por parte de la Corte Internacional de Arbitraje de la CCI, los demandados interpusieron un recurso de apelación ante los tribunales etíopes y obtuvieron una medida cautelar de la Corte Suprema suspendiendo el procedimiento arbitral hasta tanto se resolviera el citado recurso ${ }^{48}$. En forma paralela, los demandados promovieron una acción ante un tribunal judicial de primera instancia a fin de que se declarara la falta de jurisdicción del tribunal arbitral CCI en el caso y obtuvieron una medida cautelar suspensiva de similar tenor a la anterior ${ }^{49}$.

El tribunal axbitral se enfrentó a la necesidad de resolver si debía suspender el procedimiento arbitral como consecuencia de las decisiones adoptadas por los tribunales locales. En función de la línea jurisprudencial predominante en el sentido que un Estado no puede ampararse en su propia legislación a fin de desconocer un acuerdo arbitral ${ }^{50}$, el tribunal extendió ese principio a la particular situación planteada en el caso. Señaló así que

"la cuestión de si un estado puede recurrir a sus propios tribunales, no ya sólo a su propia ley, con el objeto de renegar de un acuerdo de arbitraje que libremente ha celebrado, no ha devenido

48. Salini Costruttori S.P.A. (Italia) v. The Federal Democratic Republic of Ethiopia, Addis Ababa Water and Sewerage Authority, (Caso CCI N $10.623 / \mathrm{AER} / \mathrm{ACS}$ ), laudo sobre suspensión del procedimiento y jurisdicción (7 de diciembre de 2001), Revista Latinoamericana de Mediación y Arbitraje, Vol. 49. Ibid. III, $\mathrm{N}^{\circ} 2$ (2003), p. 159

50. Ibid., párrafo 161 y siguientes. 
en una similar línea jurisprudencial bien asentada. No obstante, la cuestión se presenta, por cierto, en los mismos términos. En efecto, no hay diferencia entre, por un lado, un estado que repudia unilateralmente un acuerdo arbitral internacional o modifica sus leyes internas en un intento por liberarse de tal acuerdo y, por otro, un estado que recurre a sus propios tribunales para obtener la suspensión o terminación del procedimiento arbitral (tanto sobre la base de una alegada nulidad del acuerdo de arbitraje, una alegada parcialidad del tribunal arbitral o alguna otra razón). Tanto uno como otro equivale a que el estado reniegue de su propio acuerdo de someter controversias a arbitraje internacional" 51 .

Decisiones recientes de ciertos tribunales argentinos han generado serias dudas sobre el grado de conocimiento existente en nuestro país sobre la materia arbitral. Se ha considerado tradicionalmente que los tribunales judiciales deben abstenerse de interferir en el trámite del procedimiento arbitral hasta tanto se dicte el laudo -excepción hecha de la colaboración necesaria para la ejecución de medidas compulsivas-, ya que lo contrario implicaría limitar las facultades jurisdiccionales propias de los árbitros. Así lo contempla expresamente el ordenamiento procesal argentino al limitar los recursos existentes a la sentencia arbitral52. Lamentablemente, ciertas decisiones recientes parecen indicar que esa no es la concepción actual de algunos tribunales argentinos ${ }^{53}$.

51. Ibid., pátrafos $165-166$

52. El artículo 758 del CPCC establece: "Contra la sentencia arbitral podrán interponerse los recursos admisibles respecto de las sentencias de los jueces, si no hubiesen sido renunciados en el compromiso". Por su parte, el artículo 760 dispone: "Si los recursos hubieren sido renunciados, se denegarán sin sustanciación alguna. La renuncia de los recursos no obstará, sin embargo, a la admisibilidad del de aclaratoria y de nulidad, fundado en falto esencial del procedimiento, en haber fallado los árbitros fiera del plozo, o sobre puntos no comprometidos. En este idtimo caso, la nulidad será parcial si el pronunciamiento fuere divisible. Este recurso se resolverá sin sustanciación alguna, con la sola vista del expediente".

53. En este sentido, particular preocupación causó en el ambiente del arbitraje la intervención de algunos tribunales argentinos en el caso Yacyretá. Ver, así Juzgado Nacional de Primera Instancia en lo Contencioso Administrativo Federal $\mathrm{N}^{\circ} 3$, "Entidad Binacional Yacyretá c/ Eriday y otros", sentencia interlocutoria del 27 de septiembre de 2004, La Ley 2005-A, p. 12; Juzgado Nacional de Primera Instancia en lo Contencioso Administrativo Federal N $N^{\circ}$, "Entidad Binacional Yacyretá c/ Eriday y otros", resolución del 18 de abril de 2005, La Ley 2005-C, p. 651. Las Empresas Reunidas Impregilo - Dumez y Asociadas para Yacyretá (ERIDAY UTE) iniciaron un arbitraje CCI contra la Entidad Binacional Yacyretá (EBY) -organismo de carácter intemacional creado mediante un tratado celebrado por Argentina y Paraguay - en el marco de ciertas diferencias originadas en torno a la ejecución de un contrato para la construcción de una represa hidroeléctrica celebrado el 20 de octubre de 1983.

108 Revista Ecuatorlana de Akbitraje 
La interferencia judicial en procesos arbitrales no sólo resulta incompatible con las tendencias modernas en la materia, sino que genera serias dudas respecto a la conveniencia de aceptar ciertas jurisdicciones como sede de futuros procedimientos arbitrales. La prudencia y el respeto que ciertos tribunales judiciales han exteriorizado respecto de la autonomía del procedimiento arbitral han llevado a que tales jurisdicciones sean, por lo general, las elegidas preponderantemente a ese efecto ${ }^{54}$.

\section{II.2 El creciente sometimiento de los Estados al arbitraje}

Si bien la mayor parte de las legislaciones nacionales contemplan la posibilidad de que los particulares sometan sus controversias a arbitraje -con ciertas restricciones vinculadas con el orden público- mayores resistencias se presentan cuando una de las partes es el Estado o un ente dependiente de él.

El comercio internacional $y$, en particular, la necesidad de los Estados de financiarse en los mercados internacionales los ha llevado a admitir en forma creciente su sometimiento tanto a

Iniciado el procedimiento, se generó un debate en torno al contenido del acta de misión, que dio lugar a la recusación por parte de EBY de los tres árbitros intervinientes ante la Corte de la $\mathrm{CCI}$ en dos oportunidades. Antes que la Corte de la CCI se expidiera sobre la segunda recusación interpuesta, EBY promovió una denanda ante los juzgados de primera instancia en lo contencioso administrativo federal de la Capital Federal a fin que (i) se ordenara a ERYDAY suscribir el acta de misión incorporando las modificaciones propuestas por EBY y (ii) se excluyera a los árbitros del procedimiento arbitral. En ese marco, EBY solicitó una medida cautelar de no innovar para que el tribunal arbitral se abstuviera de proseguir las actuaciones mientras tramitara el proceso judicial. El Juzgado Nacional de Primera Instancia en lo Contencjoso Administrativo Federal $\mathrm{N}^{\circ} 3$ concedió la medida cautelar solicitada el 27 de septiembre de 2004. Para asi decidir, sostuvo que dada su importancia para el proceso arbitral no resultaba irrazonable revisar el acta de misión con anterioridad al laudo a fin de evitar futuras impugnaciones. Los árbitros designados por las partes renurciaron. La actora propuso un nuevo árbitro y fue denunciada por EBY ante el juez argentino por violación de la orden judicial suspensiva. Ante ello, una nueva resolución judicial impuso elevados astreintes a ERYDAY a fin que se abstuviera de impulsar el procedimiento arbitral hasta tanto se dictara sentencia definitiva en la causa local o cesaran los efectos de la cautelar. Respecto a este caso, ver Rivera, Julio César, "El principio de la autonomia del arbitraje. Claroscuros del derecho argentino", Academia Nacional de Derecho, Buenos Aires, Noviembre de 2005, p. L; Parodi, Víctor Gustavo, "El caso 'Yacyretá' (o cómo retroceder ochenta años). Análisis y comentarios", E.D. 215-661.

54. De acuerdo con las estadísticas de la Cámara de Comercio Internacional, de los 466 arbitrajes iniciados bajo el Reglamento de Arbitraje de la CCI en el año 2004, 88 twvieton por sede París; 65 a Londres; 44 a Génova y 25 a Zurich. Ver Lewis, James, "Centres of Power", Legal Business Arbitration Report 2006, p. 9 y siguientes. 
jurisdicciones arbitrales como a tribunales judiciales extranjeros para dirimir eventuales conflictos entre ellos y su contraparte contractual. Asimismo, la necesidad que han enfrentado los Estados de competir unos y otros por un capital limitado ha llevado a que muchos de ellos ofrezcan a los potenciales inversores garantías adicionales hasta el momento ausentes. El sometimiento de los eventuales conflictos que pudieran suscitarse en materia de inversión a arbitraje internacional -en forma directa o subsidiaria al cumplimiento de ciertos requisitos formales o temporales- visible en los más de dos mil tratados de protección y promoción recíproca de inversiones suscriptos desde 1959 a la fecha constituye uno de los compromisos más relevantes asumidos a este respecto.

El creciente sometimiento de los Estados a arbitraje resulta observable también en el ámbito local y no son ajenos a esta tendencia, incluso, los países de mayor tradición en el campo del derecho administrativo ${ }^{55}$.

En Francia, se mantiene vigente el principio general, sentado en el artículo 2060 del Código Civil y en función del cual "no se puede comprometer en árbitros (...) los conflictos relativos a colectividades públicas y establecimientos públicos y, en general, todas las materias que interesen al orden público (...)" ${ }^{\prime \prime 6}$. Este principio es aplicable tanto a la actividad administrativa como a la actividad industrial y comercial de las personas estatales y su violación trae aparejada una nulidad absoluta ${ }^{57}$.

55. Hemos decidido obviar el tratamiento del derecho italiano en este tema por corresponder a otra exposición. Sin embargo, basta mencionar al respecto que la ley italiana $205 / 2000$ dispuso en su articulo $6(2)$ que las controversias concernientes a derechos subjetivos que correspondan al conocimiento de los jueces administrativos pueden ser resueltas mediante arbitraje de derecho ("Le controversie concernenti diritti soggettivi devolute alla giurisdizione del giudice amministrativo possono essere risolte mediante arbitrato rituale di diritto").

56. El artículo 2060 del Código Civil francés -conforme a la redacción introducida por la ley 75-596 del 9 de julio de 1975-dispone: "On ne peut compromettre sur les questions d'état et de capacité des personnes, sur celles relatives au divorce et à la séparation de corps ou sur les contestations intéressant les collectivités publiques et les établissements publics et plus généralement dans toutes les matières qui intéressent lordre public (...)".

57. Con respecto a los establecimientos públicos industriales y comerciales, el artículo 2060 del Código Civil francés establece que "... no obstante, las categorias de establecimientos píblicos de carácter 
Sin embargo, tal prescripción no es absoluta ${ }^{58}$ y no constituyó -ni constituye en la actualidad- un obstáculo insuperable para el arbitraje.

En este sentido, confirmando una decisión previa del Consejo de Estado, el Conseil Constitutionnel francés ratifico en su pronunciamiento del 2 de diciembre de $2004^{59}$ que el principio enunciado en el Codigo Civil carece de valor supralegal. En función de ello, el Conseil Constitutionnel concluyó que el Estado y sus entidades pueden comprometer en árbitros mediando una ley que así lo autorice. Tal pronunciamiento no ha hecho más que ratificar una visión jurídica presente allí desde hace décadas. Desde $1906^{60}$, diversas leyes han autorizado en Francia a personas estatales a recurrir al arbitraje. Inicialmente ocasionales, el número de normas dictadas en ese sentido se ha incrementado significativamente en las últimas décadas ${ }^{61}$, ratificando la cre-

industrial y comercial pueden ser autorizadas por decreto a comprometer" ("Toutefois, des calégories d'établissements publics à caractère industriel et commercial peuvent être autorisées par décret à compromettre"). Ver Rivero, Jean y Waline, Marcel, "Droit administratif", Dalloz, $17^{\circ}$ edición, Paris, 1998, p.123 y 479; Debbasch, Charles, "Droit Administratif", Economica, $6^{\circ}$ edición, París, 2002, p. 634; Chapus, René, "Droit administtatif general" I, Montchrestien, $6^{\circ}$ edición, Paris, 1992, p. 281.

58. De Laubadère, André; Venecia, Jean-Claude; Gaudemet, Yves, "Traité de Droit Administratif", I, Libraire Générale de Droit et de Jurisprudente, $12^{\circ}$ edición, Paris, 1992, p. 257.

59. Conseil Constitutionnel, decisión $n^{\circ}$ 2004-506 DC, 2 de diciembre de 2004, Cahiers du Conseil Constitutionnel $\mathrm{N}^{\mathrm{a}} 18$

60. Sentalaba así Hauriou, al referirse a la ley del 17 de abril de 1906 que "el Estado bien podia someterse a th arbitraje en litigios internacionales, mas no podía hacerlo respecto de litigios nacionales porque en ese ámbito disponia de sus propios jueces y era considerado que no debia brindarles una prueba de desconfianza (C.E., 17 de marzo de 1983, Compagnie des chemins de fer, $R . p ., 245$ ). Esas consideraciones sentimentales terminaron por ceder ante las ventajas prácticas del arbitraje experi. mentadas a titulo oficial a propósito de la Exposición Universal de 1900 (Cf. C.E., 77, enero 1904, Ducastaing. R. p., 45). La ley de presupuesto del 17 de abril de 1906, artículo 69, revirtió el derecho existente por las disposiciones siguientes (...)" (traducción libre). Ver Hauriou, Mauricc, "Précis de droit administratif et de droit public", Dalloz, $12^{\circ}$ cdición-rcimpresión-, París, 2004, pp. 52-53.

61. Al respecto, cl Código de Justicia Administrativa francés, vigente desde cl $1^{\circ}$ de enero de 2001 , dispone en su artículo 311-6 que no obstante lo establecido en relación con la competencia de los órganos jurisdiccionales, el arbitraje es admitido en los casos previstos, entre otros, por la ley del $17 \mathrm{de}$ abril de 1906 (liquidación de gastos en contratos de obra y suministros), por la ley 82-1153 del 30 de diciembre de 1982 (orientación de los transportes interiores); por la ley $\mathrm{n}^{\circ} 86-972$ del 19 de agosto de 1986 (contratos de las colectividades locales con colectividades extranjeras); por la ley $90-568$ del 2 de julio de 1990 (organización del servicio público de correos y telecomunicaciones) y por la ley 97-135 del 13 de febrero de 1997 (crea el establecimiento público "Red férrea de Francia para el renacimiento del transporte ferroviario"). Asimismo, el nuevo Cádigo de Obras Públicas (Marchés Publics) ordenado por el decreto 2001-210 del 7 de marzo de 2001, autoriza el arbitraje para la liqui- 
ciente acogida que caracteriza al arbitraje en el campo del derecho público ${ }^{62}$.

El panorama resulta aún más alentador en el ámbito del arbitraje internacional. Las restricciones impuestas por el derecho interno francés respecto del Estado y sus entidades son consideradas inaplicables a este último campo. Particularmente ilustrativa al respecto resulta el pronunciamiento de la Cámara de Apelaciones de París en el caso Myrtoon Steamship de 1957 al señalar que "la prohibición [de comprometer en árbitros] se circunscribe a los contratos domésticos y no se aplica a los contratos de carácter internacional"63. Este tratamiento jurídico diferenciado resulta consistente con la tendencia a reconocer una amplia arbitrabilidad subjetiva en dicho ámbito, restando prácticamente toda virtualidad a las restricciones establecidas por el derecho interno.

El panorama en España es sustancialmente similar.

Por regla general, se admite el arbitraje en las contiendas que se susciten respecto de la hacienda pública estatal ${ }^{64}$ mediando real decreto acordado en Consejo de Ministros con previa audiencia del Consejo de Estado en pleno ${ }^{65}$. Idénticos requisitos son exigidos por la Ley de Contratos de las Administraciones Públicas $^{66}$ respecto de los contratos comprendidos en su ámbito

dación de los contratos de obras, suministros y servicios. En sentido concordante, ver en idioma castellano, Salcedo Castro, "La arbitrabilidad subjetiva ...", ob. cit. en nota 22, pp. 119-120 y Rosa Moreno, "El arbitraje administrativo", ob. cit. en nota 22, pp. 86-88.

62. De Laubadère, Venecia, Gaudemet, "Traité de Droit Administratif", I, ob. cit. en nota 58, p. 300.

63. La Corte de Casación francesa adoptó similar posición en el año 1966 en el caso Galakis. Ver, así, Gaillard y Savage (editores), "Fouchard Gaillard Goldman ...", ob. cit. en nota 8, p. 319; De Laubadère, Venecia, Gaudemet, "Traité de Droit Administratif", I, ob. cit. en nota 58, p. 300.

64. De conformidad con el articulo 5. I de la Ley General Presupuestaria $\mathrm{N}^{\circ} 47 / 2003$ del 26 de noviembre de 2003, "La Hacienda Pública estatal está constituida por el conjunto de derechos y obligaciones de contenido económico cuya titularidad corresponde a la Administractón General del Estado y a sus organismos autónomos".

65. Artículo 7.3 de la Ley General Presupuestaria $N^{\circ} 47 / 2003$ del 26 de noviembre de 2003. La disposición es idéntica al articulo 39 de la anterior Ley General Presupuestaria (de acuerdo con el texto refundido aprobado por Real Decreto Legislativo 1091/1988, del 23 de septiembre). Una norma similar respecto de los bienes y derechos del patrimonio del Estado se encuentra en el artículo 31 de la Ley 33/2003 del 3 de noviembre de 2003 del Patrimonio de las Administraciones Públicas.

66. Artículo 60.2 del lexto sefundido por el Real Decreto Legislativo $N^{\circ} 2 / 2000$ del 16 de junio de 2000.

112 Revista Ecuatoriana de Arbitraje 
de aplicación ${ }^{67}$ y por la Ley del Patrimonio de las Administraciones Públicas en relación con los bienes y derechos del patrimonio del Estado ${ }^{68}$, entre otras leyes ${ }^{69}$.

Aunque, por el momento sin mayor trascendencia práctica, cabe destacar que en el marco del procedimiento administrativo, el artículo 107.2 de la Ley de Régimen Jurídico de las Administraciones Públicas y del Procedimiento Administrativo Común ${ }^{70}$ autoriza el arbitraje, entre otros mecanismos alternativos, como sustituto del recurso de alzada -recurso jerárquico en la terminología utilizada en el derecho argentino-y del de reposición, sujeto a que leyes especiales así lo dispongan ${ }^{71}$.

67. Para una enumeración de los contratos excluidos, ver el artículo 3 de la Ley de Contratos de las Administraciones Públicas. En relación con los contratos que se celebren y ejecuten en el extranjero, la Ley de Contratos de las Administraciones Públicas establece que en aquéllos que se celebren con empresas españolas se incluirán cláusulas de sumisión a los Tribunales españoles y en los que sean suscriptos con empresas extranjeras "... se procurará cuando las circunstancias lo aconsejen, la incorporación de cláustas tendentes a resolver las discrepancias que puedan surgir mediante fórmulas sencillas de arbitraje. En estos contratos se podrá transigir previa autorización del Consejo de Ministros" (artículos 117.2 y 117.3).

68. Artículo 31 de la Ley $33 / 2003$ del 3 de noviembre de 2003.

69. Para una enumeración más exhaustiva de las referencias al arbitraje en normas de derecho público, ver De Martin Mut̃oz, Alberto e Hierro Anibarto, Santiago (Coordinadores), "Comentario a la ley de arbitraje", Marcial Pons, Madrid, 2006, pp. 79-83.

70. Ley $30 / 1992$, del 26 de noviembre de 1992.

71. El artículo 107.2 de la Ley de Régimen Jurídico de las Adminístraciones Públicas y đel Procedimiento Administrativo Común establece así que: "Las leyes podrán sustituir el recurso de alzada, en supuestos o ámbitos sectoriales determinados, y cuando la especificidad de la materia asi lo justifique, por otros procedimientos de impugnación, reclamación, conciliación, mediación y arbitraje, ante órganos colegiados o comisiones específicas no sometidas a instrucciones jerárquicas, con respeto a los principios, garantías y plazos que la presente Ley reconoce a los ciudadanos y a los interesados en todo procedimiento administrativo. En las mismas condiciones, el recurso de reposición podrá ser sustituido por los procedimientos a que se refiere el párrafo anterior, respetando su carácter potestativo para el interesado. La aplicación de estos procedimientos en el ámbito de Ia Administración Local no podrá suponer el desconocimiento de las facultades resolutorias reconocidas a los órganos representativos electos establecidos por la Ley". A.1 respecto, la doctrina española ha señalado la inutilidad práctica del precepto por la remisión que efectúa a las leyes sectoriales, habiéndose pronunciado, asimisıno, sobre la necesidad de intensificar la promoción del arbitraje en el derecho administrativo. Ver, asi, Garcia de Enterria, Eduardo y Fernández, Tomás-Ramón, "Curso de Derecho Administrativo", II, Thomson Civitas, $9^{\circ}$ edición, Madrid, 2004, p. 557; Rosa Moreno, "El arbitraje administrativo", ob. cit. en nota 22, pp. 97-98 y 129; Matesca Cabot, Juan Carlos, "El arbitraje en el Derecho Administrativo", en el boletín $n^{\circ} 7$ de la Associació Catalana per a L'arbitratge, Tribunal Arbitral de Barcelona, p. 47. Sobre la última oración del artículo 107.2, García de Enterría y Fernández hacen notar la escasa claridad del precepto y la consiguiente dificultad de comprenderlo. En su opinión, la última parte de la norma estaría indicando que “... los drganos colegiados o comisiones especificas que puedan establecerse por las Leyes para resolver estos procedimientos alternativos en el ambito local habrán de limitarse a formular meras propuestas de resolución y elevar a éstas a la ulterior decisión de los órganos representativos de cada Corporación, órganos que son expresión del principio democrático". Ver, así, García de Enterría y Fernández, "Curso de Derecho Administrativo", II, ob. cit nota 71, p. 557. 
Distinta es la situación en lo que respecta al arbitraje internacional, ante la sanción de la nueva Ley de Arbitraje $\mathrm{N}^{\circ}$ 60/2003 del 23 de diciembre de 2003. Inspirada en este aspecto en el régimen jurídico suizo ${ }^{72}$, el artículo 2.2 de la nueva ley dispone que "cuando el arbitraje sea internacional y una de las partes sea un Estado o una sociedad, organización o empresa controlada por un Estado, esa parte no podrá invocar las prerrogativas de su propio derecho para sustraerse a las obligaciones dimanantes del convenio arbitral".

De ese modo, la norma ha establecido una regla material en función de la cual el convenio de arbitraje prevalece sobre las normas nacionales aplicables a la parte estatal, aun aquéllas de carácter imperativo o de orden público interno ${ }^{73}$. De ello se deriva que el Estado y sus entidades se encuentran impedidos de alegar la falta de arbitrabilidad subjetiva fundándose en su legislación interna ${ }^{74}$. Aún cuando podrá debatirse el grado de eficacia de semejante disposición ante la eventual sanción de normas de grado similar en sentido contrario, la nueva regulación del arbitraje denota la voluntad de las autoridades españolas de compatibilizar su régimen jurídico con el desarrollo del arbitraje internacional, de modo tal que su propio derecho interno no constituya un límite para ello.

El panorama en el derecho argentino es sustancialmente más complejo ${ }^{75}$.

72. Mantilla-Serrano, Fernando, "Ley de Arbitraje. Una perspectiva internacional", Iustel, Madrid, 2005, p. 48.

73. Ibid.

74. De Martín Muñoz e Hierro Anibarto (Coordinadores), "Comentario a la ley de arbitraje", ob. cit. cn nota $69, \mathrm{pp} .751 .752$.

75. Como bien expresaba Velar de Irigoyen hace más de 50 años, "la concertación del arbitraje en los contralos en que la Nación es parte, lejos de haber logrado abreviar la solución de las divergencias, $y$ que es lo que constituye la esencia del arbitraje, ha sido fuente fecunda de litigios de carácter previo para establecer en forma inequivoca la procedencia o improcedencia del arbitraje, su extensión o limites, su legalidad o la capacidad del Estado para obligarse por ese procedimiento". Cfr. Velar de Irigoyen, Bernardo, "El Estado y la cláusula arbitral. Resultados de una experiencia", La Ley 60949 , p. $953(1950)$.

114 Revista Ecuatoriana de ARbitraje 
En relación al Estado y su aptitud para comprometer en árbitros, tanto la doctrina como la jurisprudencia se han ocupado del tema, sin efectuar distinción, en general, entre el arbitraje local y el internacional.

La principal discusión en este sentido se centra en el alcance a otorgar al anterior artículo 100 (actual artículo 116) de la Constitución Argentina ${ }^{76}$.

Para un sector de la doctrina, en la medida en que dicha norma establece la jurisdicción federal exclusiva en "los asuntos en que la Nación sea parte", no sería constitucionalmente válido sustraer esa clase de conflictos de los tribunales federales para dirimirlos en arbitraje.

Por esa posición se pronunció el entonces Procurador del Tesoro de la Nación Enrique Bacigalupo en su dictamen del 25 de junio de 197377, al señalar que: "... al estar dispuesto en la Constitución que las causas en que la Nación es parte son de competencia de la justicia nacional (art. 100), es claro que ello no solo no resulta modificable por la voluntad de las partes (art. 1197 Cód. Civ.) sino que tampoco lo es por ley del Congreso, dado que éstas no pueden alterar lo reglado por la Constitución"78.

76. Ver, al respecto, Bianchi, Alberto B., "Los poderes del Congreso para crear y reglamentar la jurisdicción de los tribunales federales", La Ley 1992-B, p. 863 y "El Estado ante el arbitraje", La Ley 2005 $\mathrm{B}, 1145$.

77. Dictámenes 125:382. Entre otras tazones, el Procurador fundó su posición en un fallo de la Corte Suprema del año 1936 -"Compte y Cía., Miguel c/ Ybarra y Cía.", Fallos: 176:218-, en el cual el más alto tribunal declaró inválida una cláusula de prórroga de jurisdicción a favor de los tribunales de Sevilla en un contrato de fletamento de carácter internacional entre dos partes privadas. La Corte entendió que la jurisdicción federal en materia mańtima no podia ser prorrogada por acuerdo de partes incluso en contratos de carácter internacional a la luz de lo previsto en el artículo 1091 del Código de Comercio que establecia que "el contrato de fletamento de un buque extranjero que haya de tener ejecución en la Repuiblica debe ser juzgado por las reglas establecidas en este código, ya haya sido estipulado dentro o fuera de la República". Relacionado dicho artículo con el inciso 10 del artículo 2 de la ley 48 , el alto tribunal consideró que la justiciá federal resultaba competente con carácter exclusivo. Pese a la interpretación restrictiva que efectúa la Corte Suprema, abandonando en el caso su doctrina de Fallos: 138:62, no parcec posible deducir de clla que el máximo tribunal haya considerado que el articulo 100 -hoy 116- de la Constítución Nacional prohíbe la prórroga de jurisdicción federal en razón de la materia aún cuando fuera dispuesta por ley del Congreso. La Corte fundó sus conclusiones esencialmente en argumentos de tango legal más que de naturaleza constitucional.

78. Este criterio fue inicialmente esbozado en un dictamen del entonces Procurador Genetal de la Nación José Nicolás Matienzo (Fallos: 129:243, publicado en J.A. 3-349) y encontró recepción, asimismo, en alguna jurisprudencia de la Cámara Federal de la Capital Federal -Unión de Fabricantes de Tejidos de Yute de España c/ la Nación, J.A. 40-336), así como en disidencias de los Ministros de la Corte 
Guido Santiago Tawil e Ignacio J. Minorini Lima

Suprema Nazar Anchorena y Ramos Mejia (Fallos: 194:155). Ver, asimismo, Spota, Alberto G., "La cláusula compromisoria en el derecho administrativo", J.A. 1943-I, 603, p. 604 nota al pie 1. Resulta interesante transcribir las palabras vertidas por Matienzo en aquella oportunidad por la particular desconfianza que expresa respecto del arbitraje: "La constitución nacional coloca entre las atribuciones del poder judicial el conocimiento y decisión de los asuntos en que la nación sea parte (articulo 100). Comentando una disposición análoga de la Constinción de los Estados Unidos, dijo Hamilton que cualquier otro plan sería contrario a la razón a los precedentes y al decoro. No parecen haber entendido lo mismo los gobiernos angentinos que han convenido con empresas particulares someter los asuntos de la nación a la decisión de árbitros o de arbitradores. Los jueces permanentes de la Nación son nombrados por el poder ejecutivo con el acuerdo de la cámara de senadores, sin relación con ninguin asunto determinado, funcionan bajo el control del foro y de la opinión pública y son legalmente responsables ante el congreso. Sis fallos están asi rodeados de garantias de verdad y de imparcialidad y la nación puede entregarles en confianza la solución de sus contiendas con el interés privado. Pero los árbitros deben su nombramiento al interés inmediato de las partes en el asunto que motiva el nombramiento, y no están sujetos a las fiscalizaciones y responsabilidad de los jueces permantentes. Nacen para la decisión que dictan y mueren con ella, sin que el público lo advierta casi ni pueda apreciar su idoneidad por una serie de sentencias dictadas con casos y circunstoncias diversas, como ocurre con aquellos jueces. De ahí que, salvo raras excepciones, el arbitro no obra como juez sino como defensor del litigante que lo nombra; $y$ de athi que el tercero en discordia prefiere casi siempre las soluciones aparentemente equitativas que evitan dar todo su derecho al que lo tiene. Asi, no es extraño que los laudos resulten, por lo general, arbitrarios, no sólo por su origen. sino por su contenido. Se explica que los particulares poco seguros de su derecho pongan más esperanzas en los drbitros y arbitradores que en los jueces permanentes; pero no es, en mi concepto, razonable que los gobiernos procedan lo mismo, con menoscabo del decoro del poder judicial de la nación que aparece apartado como inútil o ineficaz. Estas consideraciones, si no fueran suficientes para demostrar la inconstitucionalidad de someter a árbitros los astuntos en que la nación es parte, bastan, por lo menos, para justificar que toda duda sobre la procedencia del arbitraje en los asuntos de la nación se resuelva en favor de la jurisdicción de los tribunales permanentes. Como quiera que sea, hay una distinción que me parece indispensable hacer. La nación puede obrar como persona jurídica o en su calidad de entidad soberana. En el primer caso, pudiera admitirse la discusión acerca de la procedencia del arbitraje; en el segundo caso, no. El soberano abdicaria su dignidad si sometiera al fallo de árbitros privados la existencia o extensión de sus facultades gubernativas. La sentencia apelada no ha hecho esta distinción e interpreta el art. 15 de la ley 2346 como obligando al gobierno a someter al juicio de arbitradores todas las cuestiones que strjan entre el poder ejecutivo y los concesionarios del canat de navegación entre el antepuerto del Riachuelo y la Estación Mitre, aunque alguna de esas cuestiones afecte las facultades constitucionales del Congreso. Yo creo que no es propio atribuir al Congreso esa intención. Lo que en mi entender quiso el congreso al dictar la disposición mencionada fué tan sólo someter a arbitraje las cuestiones en que la nación aparece como persona juridica, como persona del derecho civil, en igualdad de condiciones que la orra parte contratante. El art. 15 dice texthalmente ast: 'Las cuestiones que surgieren entre los concesionarios y el poder ejecutivo 'sobre la manera de cumplir las obligaciones que la ley de concesión les impone'serín sometidas al juicio de arbitradores nombrados por una y otra parte, debiendo éstos nombrar, antes de empezar sti tarea, un tercero para el caso de discordia. quien fallará definitivamente en los astutos que le fiveren sometidos'. Cuestiones sobre la manera de cumplir las obligaciones impuestas a los concesionarios serian las relativas al plazo señalado para la realización de los trabajos, a la conformidad de las obras con las planos, a la calidad de los materiales y otros semejantes. Pero la duda sobre si la empresa tiene derecho a percibir el imptuesto de permanencia en el puerto no se refiere a la manera de cumplir sus obligaciones, sino a la facultad del congreso para establecer esa clase de impuestos, faculiad en que la nación obra en calidad de potencia soberana. Está bien que los tribunales creados por la constitución decidan sobre el alcance de las facultades del congreso; pero sería impropio y peligroso violentar el sentido expreso de una clausula de concesión para autorizar a los empresarios particulares a nombrar árbitros que resuelvan definitivamente sobre el ejercicio de los poderes constitucionales. Por estas consideraciones y las expuestas par el Ministerio Fiscal en $1^{a}$ y $2^{a}$ instancia, pido a V.E. se sima declarar que este asunto corresponde a la justicia federal, revocando la sentencia de la cámara de la capital, con costas".

\section{ReVISTA Ecuatorlaina dE ARBMtraje}


En una variante de esta primera posición, autores como Bidart Campos ${ }^{79}$ efectuaron ciertas distinciones basadas en una particular interpretación del precepto constitucional. Para ellos, la jurisdicción federal en los asuntos en que la Nación sea parte podrá válidamente prorrogarse desde una perspectiva constitucional únicamente cuando ella surgiera en razón de la persona. En cambio, en el caso que la jurisdicción federal correspondiera en razón de la materia, ello constituiría un obstáculo constitucional para la prórroga, toda vez que en esos casos la Constitución prescribe la jurisdicción federal para "... todas las causas que versen sobre puntos regidos por la Constitución, y por las leyes de la Nación, con la reserva hecha en el inciso 12 del artículo $75 ; y$ por los tratados con las naciones extranjeras", resultando ella, entonces, exclusiva y excluyente de cualquier otra ${ }^{80}$.

La Corte Suprema tiene dicho que la jurisdicción federal establecida por la Constitución Nacional para los juicios en que la Nación es parte no excluye la jurisdicción arbitral ${ }^{81}$. Sin embargo, los casos y requisitos bajo los cuales se admite el consentimiento del Estado a arbitraje no han encontrado una clara respuesta en la jurisprudencia de la Corte Suprema ${ }^{82}$. Si bien es

79. Ver, asi, Bidart Campos, Germán J., "Manual de la Constitución Reformada", $\Upsilon$. III, EDIAR, Buenos Aires, 1997 , p. 477 . En relación con el ámbito intemacional, este autor limitaba su interpretación sobre la inconstitucionalidad de la prórroga de jurisdicción federal en razón de la materia a la prórtoga en favor de tribunales extranjeros, no de tribunales intemacionales (Ibid., p. 556).

80. Por una posición alternativa sobre is arbitrabilidad del Estado se pronunciaba el Profesor Miguel S. Marienhoff. Apartándose de las posiciones precedentes, Mariethoff sostenia que la facultad de comprometer en árbitros constituía una atribución del Poder Ejecutivo, cuando éste resultara constitucionalmente admisíble. En su opinión, no podia verse en ello una excepción al fuero federal, sino el mero ejercicio de una competencia constitucional propia de ese poder del Estado que derivaba de sus atribuciones de administración general. Ver Marienhoff, Miguel \$., "Tratado de Derecho Administrativo", III-A, Abeledo Perrot, Buenos Aires, 1994, p. 599.

81. Fallos: 178:293 del 16 de agosto de 1937. Entre otros autores, Bielsa sostenía que el artículo 100 de la Constitución no tiene otro objeto que el de delimitar la competencia de los tribunales federales, pero de ningún modo excluyc la jurisdicción arbitral. Añadia que "... es elemental que todo el que en caso contencioso debe someter sus decisiones a la justicia federal, puede obligarse, por contrato, a un compromiso arbitral, a menos que sea una cuestión de orden puiblico, o que la ley expresamente lo prohiha (...) no es inoportuno agregar que la solución arbitral está consagrada en el derecho público y hasta es obligatoria en ciertos casos. Y eso explica la misma naturaleza y substancia moral del arbitraje. Por ejemplo, el arbitraje es un procedimiento obligatorio en contratos administrativos como el de obras públicas (ver arts. 38, 39, 41 y 71 de la ley 775), y en el de concesion; de ahi que leyes como la $n^{\circ} 3885$, sobre concesión del puerto de Rasario, instituyen el arbitraje, siendo la Nación parte (art. 13). Es también aplicable el arbitraje para determinar la indemnización de daños y perjuicios causados por mal servicio telegráfico". Ver Bielsa, Rafael, "Estudios de Derecho Público", I, Depalma, Buenos Ajres, 1950, pp. 286 y 306-307.

82. En similar sentido se pronuncia Bianchi, “Los poderes...," ob. cit. en nota 75, p. 875. 
posible extraer de ella algunos principios en la materia, subsisten ciertos interrogantes, producto de algunas imprecisiones y la falta de delimitación concreta de los límites a partir de los cuales no resulta admisible el compromiso en árbitros.

En líneas generales, el alto tribunal ha sostenido que nada obsta a que el Estado comprometa en árbitros en aquellos casos en que actúa como persona jurídica ${ }^{83}$ o cuando una ley así lo autorice $^{84}$. Por el contrario, el arbitraje se hallaría vedado en

83. En Gerardo Pagano c. Estado Nacional s/ constitución de tribunal arbitral (Fallos: 133:61), la Corte sostuvo que "... ningún principio de orden público se opone a que la institución del arbitraje sea practicada por el estado como persona juridica, a los fines de dirinir sus controversias con los partictilares; y establecida dicha institución por la ley e incorporada a un contrato, como en el caso de autos, debe producir los efectos que en términos generales establece el art. 1197 del código civil, todo vez que las obligaciones creadas por convenciones bilaterales no pueden modificarse ni extinguirse por voluntad de una sola de las partes...". No puede onitirse señalar que en ese caso la Corte se expidió sobre la procedencia del arbitraje en un contrato de naturaleza administrativa. A la luz de los articulos 38 y 39 de la ley 775 de obras públicas, derogada por la actualmente vigente ley 13.064 , el máximo tribunal ordenó la constitución de un tribunal arbitral para dirimir una controversia suscitada en relación con un contrato para la construcción del loospital común regional de Río Negro. Un caso similar sc presentó en Puerto de Rosario c. Gobierno Nacional (Fallos: 152:347 del 26 de septiembre de 1928). La controversia se originó por desavenencias en el marco de un contrato para la construcción y opcración de un puerto comercial en la ciudad de Rosario, en cuyo texto se habia estipulado una cláusula arbitral para dirimir las dificultades que podrían suscitarse (el artículo 13 de la ley 3885 que habia autorizado y dispucsto los términos gencrales a los cuáles debia sujetarse la contratación autorizaba al Poder Ejecutivo "... para aceptar la jurisdicción arbitral en el contrato que firme con el concesionario"). De la lectura de la ley 3885 , en cuyo marco se habia procedido a la contratación, se puede colegir que el contrato no era sino una suerte de concesión de obra pública. No obstante ello, la Cortc Suprema entendió que cl recurso al arbitraje era procedente cn tanto la cláusula compromisoria se referia al Estado en su carácter de persona jurídica y consideró que la Nación no actuaba en el caso como "... entidad politica soberana y en su carácter exclusivamente publico dentro del cual le incumbe la función de percibir las rentas y darles la correspondiente aplicación ...". En Nicolds Mihanovich Lida. c. Fisco Nacional (Fallos: 160:134 del 18 de marzo de 1931), el alto tribunal sostuvo: "que existiendo en las leyes generales la determinación del juicio arbitral, y habiendo declarado los tribunales del fuero competente, que ha llegado el caso de convocar los árbitros, nada se opone a que el fisco, como persona juridica, se someta a la jurisdicción arbitral, toda vez que dentro de aquel carácter $y$ en sus relaciones con los particulares, le comprenden los códigos comunes". Puede observarse a partir de los fallos citados que (i) en todos los casos mediaba una ley que autorizaba o disponía el arbitraje y (ii) la Corte se refiere al Estado como persona juridica (acogiendo la teoría de la doble personalidad del Estado) tanto en el caso Pagano como en Puerto de Rosario cuando dificilmente pudjeran calificarse los respectivos contratos como "de dereche común". En opinión de Marienhoff, esta última suerte de contradicción de la Corte Suprema se debe a una confusión respecto de la calificación de la náturaleza del contrato. Ver Marienhoff, "Tratado de Derecho ...", III-A, ob. cit cn nota 80, p. 597. En Cia. Lalo Argentina de Electricidad v. La Nación s/ constitución de tribunal arbitral (Fallos: 178:293 del 16 de agosto de 1937), la Corte Suprema admitió el arbitraje pactado en un contrato de compraventa de cnergía eléctrica para el puerto de la Capital Federal, cn tanto sostuvo que "... es evidente que el Estado puede actuar también como simple persona juridica, que contrata como un ente de derecho privado ...".

84. En el caso "Guido Simonini c. La Nacion" (Fallos: 194:155 del 4 de noviembre de 1942), controversia relativa a la interpretación de un contrato sobre servicio de alumbrado público y privado, cuya 
aquellas cuestiones que lo afecten como poder público o en las atribuciones de la soberanía ${ }^{85}$.

Diversas han sido las interpretaciones que los autores han construido a partir de los pronunciamientos de la Corte. Para cierto sector de la doctrina el tribunal supremo admitiría el arbitraje en los contratos "de derecho privado" de la Administración sin que resulte necesaria ley alguna al respecto y exigiría autorización legislativa en los contratos administrativos propiamente dichos ${ }^{86}$. Otros autores han entendido que únicamente procedería el arbitraje cuando el Estado actuara como persona jurídica ${ }^{87}$. Por último, para una tercera posición, tanto en el campo del derecho público como del derecho privado debería mediar una ley que autorice el sometimiento a árbitros ${ }^{88}$.

naturaleza administrativa dificilmente pudiera ser cucstionada, la Corte no efectuó distinciones en relación al carácter en virtud del cual fue celebrado cl contrato y clarificó que de sus fallos se derivaba "la validez del compromiso arbitral en los contratos en que es parte el gobierno de la nación. cuando éste, autorizado por tuna ley, ha creido conveniente pactarlo ...". Por su parte, en Cayetano Paino v. Nación Argentina y Soc. Arrigo Hnos. (Fallos: 235:940), la Corte sostuvo "que en materia de competencia, el texto constittcional invocado establece que la tendrán los tribunales nacionales para conocer y decidir de todos los asuntos en que la Nación sea parte; principio general que ha sido interpretado por esta Corte en el sentido de que no obsta al sometimiento de esos asuntos a la jurisdicción arbitral cuando así se hubiere pactado en contratos de acuerdo con leyes especiales dictadas por el Congreso o cuando la Nación actuare como persona juridica".

85. En Cia. Italo Argentina de Electricidad v. La Nación s/ constitución de tribunal arbitral (Fallos: 178:293 del 16 de agosto de 1937), la Corte Suprema sostuvo que no eran susceptibles de ser comprometidas en árbitros las cuestiones que afecten al Estado como poder público o las atribuciones de soberanía. En el caso, la Corte resolvió que la discusión relativa al precio de la unidad eléctrica a partir de determinada fecha en el marco de un contrato de compraventa de energía para satisfacer las necesidades de! puerto de la Capital Federal no afectaba atributo de la soberanía alguno.

86. Ver Marienhoff, "Tratado de Derecho ...", III-A, ob. cit. en nota 80, p. 595 y siguientes. Sin embargo, este autor disiente con la doctrina de la Corte (ver nota al pie 80 al presente trabajo).

87. Esta parece ser la lectura que realizaba Zavalia de los pronunciamientos de la Corte con anterioridad a 1941 al afirmat que "ia Corte Suprema en reiterados fallos ha sentado el juicioso principio de que si en los contratos en los cuales la Nación actía como persona jurídica, se ha pactado el arbitraje, nada se opone a que los representantes de aquella concurran a constituir el tribunal'. Ver Zavalía, Clodomiro, "Derecho Federal", I, Compañia Argentina de Editores, $3^{\circ}$ edición, Buenos Aires, 1941, pp. 413-414)

88. Al respecto, afirmaba Velar de Irigoyen que en relación al arbitraje deben tenerse en cuenta “... las orientaciones que surgen de los fallos judiciales sin perdernos en disquisiciones doctrinarias. Partamos de la base de que ningín precepto constitucional impide, en principio, que la Nación concierte arbitraje cuando actía en el carácter de persona juridica: que el compromiso encuentra un límite en lo que pueda afectar el orden piblico o el ejercicio de la soberania, y para no caer en el error, dado que esas expresiones no pueden ajustarse a reglas fijas, creemos que to razonable es su aceptación para cuestiones de hecho. de carácter técnico y meramente patrimoniales y, en todos los casos, que el arbitraje haya sido autorizado por ley". Ver Velar de Irigoyen, "El Estado y la cláusula ...", ob. cit. en nota 75, p. 953. Alberto G. Spota opinaba que el artículo 100 de la Constitución 
Tampoco existe acuerdo en relación a los límites materiales que la Corte ha establecido para la admisibilidad del arbitraje. En este sentido, referencias a conceptos tales como el de orden público, la soberanía y la afectación al Estado como poder público permitirían distintas lecturas ${ }^{89}$.

Los pronunciamientos de la Corte no permitirían sostener que el arbitraje se encuentre prohibido en materia de contratos administrativos. Del mismo modo que en los supuestos en que la Administración actúa en el campo del derecho privado puede recurrir al arbitraje porque la ley común así lo admite ${ }^{90}$, para comprometer en árbitros en el ámbito del derecho administrativo resultaría necesaria una autorización legislativa otorgada en términos generales o particulares.

Los límites que la Corte Suprema ha establecido a la jurisdicción arbitral, más que fundarse en la naturaleza del contrato o la materia de la controversia -federal o común-parecen haberse centrado en declarar que las cuestiones que afectan el orden

Nacional (hoy 116) no prohíbe la función del árbitro -a la que no caracterizaba como jurisdiccional-, porque ella no importa sustraer la jurisdicción acordada al fuero federal por la norma suprema. Agregaba a ello, con apoyo en "Guido Simonini c. La Nación" (Fallos: 194:155), que "la Administración no puede comprometer en árbitros una cuestión sin que ostente una atribución expresa del legisiador (art. 1881, inc. $3^{\circ}$, C.C.). Cuando la Administración actia en la esfera mercantil o civil, te es aplicable lo dispuesto por las leyes civiles o mercantiles que imponen el arbitraje forzoso, $v$ gr, en materia de locación de servicios (art. 1627. C.C.) o en los supuestos ya recordados del derecho maritimo. Además, et derecho administrativo local, organizado por el legislador también local, puede autorizar o imponer a la Administración el arbitraje: tal es lo que ocurre con las pertinentes disposiciones de las leyes de obras puiblicas. En estos supuestos, el legislador provincial actúa dentro de las esfera de su órbita, al organizar un derecho que, como el administrativo, es local, salvo en la materia delegada al poder central (arts. 104 a 107, Const. Nac.)". Ver Spota, "La cláusula compromisoria ...", ob. cit. en nota 78, p. 614.

89. Ver, entre otros, Bielsa, "Estudios de Derecho Público", I, ob. cit. en nota 81, pp. 286 y 306-307; Velar de Irigoyen, "El Estado y la cláusula ...", ob. cit. en nota 75, p. 953; Spota, "La cláusula compromisoria ...", ob. cit. en nota 78, p. 603 y siguientes. Este último autor, expresaba sobre el punto: "... ast como el particular no puede dejar de lado aquellas leyes en cuya observancia estén interesados el orden piblico y las buenas costumbres (arts. 21 y 953, C.C.). asi también el Estado no puede comprometer en árbitros nada que proceda incluir en esa materia donde se cierne la publica wilitas" (lbid., p. 608).

90. Al respecto, y estrechamente vinculado con la tcoría del órgano, se ha debatido si resulta aplicable al Poder Ejecutivo lo dispuesto en el artículo 1881, inciso 3, del Código Civil que exige poder especial -ley especial en el caso- para transigir, comprometer en árbitros y prorrogar jutisdicciones. Ver sobre el punto Spota, "La cláusula compromisoria ...", ob. cit. en nota 78, p. 614; Marienhoff, "Tratado do Derecho ...", III- $\Lambda$, ob. cit. cn nota 80 , pp. 599-60I 
público no son susceptibles de comprometerse en árbitros, independientemente del ámbito -público o privado- en el que el Estado actúe.

Particular relevancia en esta materia asume el análisis efectuado por el Procurador General de la Nación Oscar Freire Romero el 4 de septiembre de 1974 en la causa "Yacimientos Petroliferos Fiscales v. S.A. Sargo Argentina" ${ }^{\prime \prime 1}$. Sostuvo él en esa ocasión que la prórroga de la jurisdicción federal en favor de tribunales arbitrales no encontraría óbices constitucionales sea que dicha jurisdicción correspondiera en razón de las personas o de la materia, en tanto la prórroga fuera dispuesta o autorizada por ley del Congreso, organo que posee el poder privativo de establecer y determinar la jurisdicción y competencia de la justicia federal.

Para así opinar, el Procurador se apoyó parcialmente en doctrina y jurisprudencia norteamericana en relación con el artículo III, sección segunda, de su Constitución -fuente inspiradora de los actuales artículos 116 y 117 de la Constitución Argentina- que confiere al Congreso la potestad de (i) crear los tribunales inferiores y determinar la extensión de su jurisdicción en el grado y carácter que estime adecuado para el bien público y (ii) establecer los casos en que procede la jurisdicción apelada de la Suprema Corte ${ }^{92}$.

91. Fallos: 290:458.

92. El Procurador concluyó que “... corresponde interpretar el art. 100 de nuestra Ley Fundamental, en lo concerniente al carticter de la jurisdicción de los tribunales federales inferiores, de igual manera a como lo ha sido su fuente, el Art. HI, sec. 2a., de la Constitución de los Estados Unidos, habida cuenta, además, que el art 94 de nuestra Carta, análogo al Art. $\mathrm{HI}$. sec. la. de la norteamericana tampoco utiliza términos inexcusablemente imperativos acerca de la creación de tribunales federales inferiores". Recordo el Procurador que, en sus fallos, la Corte Suprema argentina ratificó, por ejemplo, la potestad del Congreso de eliminar por completo la competencia federal de los tribunales inferiores cuando existieran motivos razonables que así lo justificaran. Sostuvo asi en junio de 1904 (Fallos: 99:383): "Que no obstante la generalidad de los términos de los art. 67, inc. 17, 94 y 100 de la constitución, que disponen que el poder judicial de la nación, en los casos regidos por las leyes nacionales y otros. fuera de los códigos, será ejercida por una corte suprema de justicia y por los demás tribunales inferiores que el congreso establezca, aquéllos han sido siempre entendidos en la reptiblica y en los Estados Unidos, cuya constitución es la fuente reconocida de los mismos, en el sentido de que ni se oponian a exclusiones completas de los tribunales federales en caso de no existir los propósitos que los informan, por lo escasa importancia civil o penal de dichos casos, u otros motivos, ni a la investidura de jurisdicción en distintas autoridades, con recurso para ante los tribunales referidos...". 
Pese a compartir, en términos generales, la interpretación desarrollada por la Suprema Corte norteamericana, el Procurador se apartó de ella en relación con la jurisdicción apelada del máximo tribunal argentino. Mientras que en aquel país, se ha sostenido mayoritariamente que el Congreso tiene poder suficiente para limitar e incluso excluir la competencia apelada de la Corte ${ }^{93}$, el Procurador esbozó una posición diferente al entender que "por ser constitucionalmente obligatoria la jurisdicción apelada de la Corte Suprema en materia federal, las cuestiones del mismo carácter sustraidas por el legislador al conocimiento de los jueces inferiores de la Nación, no pueden quedar, por esa circunstancia, excluidas de revisión por parte de aquel Tribunal"94.

La Corte Suprema estimó innecesario considerar en el caso si el artículo 100 de la Constitución impediría comprometer en árbitros las causas en que la Nación es parte. Toda vez que el compromiso arbitral preveía la posibilidad de impugnar el laudo por nulidad, el alto tribunal consideró inoficioso referirse a la factibilidad de excluir la competencia apelada de la Corte al no cuestionarse la admisibilidad del recurso extraordinario contra la sentencia que rechaza la pretensión anulatoria ${ }^{95}$. Agregó también que "... al admitir el compromiso arbitral recurso por nulidad del laudo, en el caso -supuesto de jurisdicción interna en que no se cuestionan poderes públicos del Estado y promedia expresa autoriza-

93. Ver Tribe, Laurence H., "American Constitucional Law", The Foundation Press, Nueva York, 1978, p. 33 y siguientes; Gunther, Gerald, "Constitutional Law", The Foundation Press, $11^{\circ}$ edición, Nueva York, 1985, p. 40 y siguientes; Convin, Edward S., "La Constitución de los Estados Unidos y su significado actual", editorial Fraterna, Buenos Aires, 1987, p. 294, entre muchos otros.

94. Sobre el punto, el hecho que el actual artículo 117 de la Constitución al hacer referencia a la jurisdicción apelada de la Corte Suprema la condicione a "las reglas y excepciones que prescriba el Congreso" otorga sustento suficiente para apartarse de esa posición y entender que el Congreso puede restringir y excluir la competencia federal, se trate tanto de tribunales inferiores como de la Corte Suprema. La reforma efectuada oportunamente al CPCC por la ley 23.774 , autorizando a la Corte Suprema de Justicia a no ejercer su competencia apelada en aquellos supuestos que se consideren insustanciales o carentes de trascendencia resulta un claro ejemplo de ello. Tanto en los Estados Unidos como en la Argentina el limite de la intervención del Congreso se encuentra en que se trate de jurisdicción apelada. Por el contrario, desde "Marbury v. Madison" (1 Cranch 137 (1803)) en los Estados Unidos y el caso "Sojo" (Fallos: 32:120 (1887)) en la Argentina, los altos tribunales de ambos paises han sostenido invariablemente que, por el contrario, resulta ajena al Congreso la regulación de su competencia originaria por resultar ella propia de la normativa constitucional.

95. Fallos: $290: 458$, cons. 6 . 
ción especifica del Congreso-, no cabe desconocer la existencia del proceso arbitral como actuación cumplida de las partes y del árbitro, pero sí juzgar de sus efectos jurídicos como se hace en la presente sentencia $(\ldots)^{\prime \prime 96}$.

Similar posición adoptó la Procuración del Tesoro de la Nación, tras abandonar rápidamente el criterio sentado en el dictamen del 25 de junio de 1973, anteriormente referido. Señaló así el organismo asesor el 14 de agosto de 1973, en relación con la misma contratación sobre la que recayera el pronunciamiento referido y tan sólo dos meses después de su opinión anterior, mediante dictamen suscripto en esta ocasión por el entonces Subprocurador del Tesoro Adalberto Enrique Cozzi que "... el art. 100 de la Constitución Nacional no se opone -no estando comprometido el Estado como poder público- a que éste se someta voluntariamente a jueces extranjeros, siempre que esa voluntad se manifieste por la genuina representación del pueblo, mediante una ley del Honorable Congreso de la Nación que lo autorice expresamente".

Debe destacarse particularmente el referido dictamen por clarificar que el actual artículo 116 de la Constitución Nacional "tiene únicamente el alcance de un deslinde dentro de la jurisdicción interna, que no alcanza a los casos en que, por aplicación de normas y principios de derecho internacional (público o privado), puede proceder la jurisdicción internacional extranjera". Como bien se señaló en aquella ocasión, una lectura rígida de la disposición constitucional derivaría en situaciones absurdas, tales como sostener que el Estado no podría siquiera litigar en el extranjero o ante tribunales arbitrales o de justicia internacional como la Corte Internacional de Justicia.

Lo expuesto permite advertir que, en general, ni la Corte Suprema ni la Procuración del Tesoro de la Nación han distinguido el arbitraje local del internacional. En las raras excepciones en que tal distinción fue realizada -como, por ejemplo, en la

96. Fallos: $290: 458$, cons. 25. 
opinión de Cozzi anteriormente señalada-97 el análisis efectuado no profundizó respecto a las consecuencias que de ella podrían desprenderse.

Más allá de ciertas disidencias, parece existir cierto consenso en la doctrina y jurisprudencia en que la Constitución Nacional no prohíbe que el Estado comprometa en árbitros conflictos con particulares en materia de contratos administrativos o que involucren materia federal, siempre que una ley del Congreso así lo autorice con el único límite de las cuestiones que afecten el orden público ${ }^{98}$.

Queda todavía pendiente, sin embargo, deslindar adecuadamente el régimen jurídico aplicable al arbitraje doméstico del internacional. En el actual estado del derecho comparado, la tendencia mayoritaria es la de reconocer una mayor amplitud de la arbitrabilidad objetiva y subjetiva en este último campo. En ese mismo contexto internacional, la afirmación -reiterada por la doctrina y jurisprudencia nacional ${ }^{99}$ - de que el Estado no puede comprometer en árbitros aquellas cuestiones que lo afectan como poder público o involucran el orden público parece haber perdido hoy en día vigencia.

97. La correcta limitación del ámbito de aplicación del articulo 116 de la Constitución Nacional al ámbito interno efectuada por el Subprocurador Cozzi no fue mantenida en recientes pronunciamientos. En ellos, no sólo nada se dijo sobre el ámbito de operatividad de dicho artículo, sino que en virtud de él -y en lo que puede calificarse como un retroceso en la materia- se afirmó la improrrogabilidad de la jurisdicción en favor de tribunales extranjeros en los casos en que corresponda la jurisdicción federal por razón de la materia. Ver, así, Dictámenes 253:55.

98. Tal es el caso de la ley permanente de presupuesto que faculta al Poder Ejecutivo a comprometer en árbitros en materia de contratación de préstamos con organísmos internacionales económico-financieros en los que participe como miembro la República Argentina, sin perjuicio de la discusión sobre si la emisión de bonos por parte del Estado Nacional se trata efectivamente de un contrato y, eventualmente, la naturaleza administrativa o de derecho privado que reviste. Cabe recordar que, si bien no en relación con este tìpo de préstamos a organismos internacionales, la Corte Suprema se inclinó en el caso "Brunicardi" por considerar que el empréstito público establece una relación de desecho público (Fallos: 319:2886).

99. Entre muchos otros casos, ver Fallos: 290:458 (27 de diciembre de 1974). Ver, entre otros, Marienhoff, "Tratado de Derecho ...", IIJ-A, ob. cit. en nota 80, p. 595 y siguientes; Bielsa, "Estudios de Derecho Público", I, ob. cit. en nota 81, pp. 286 y 306-307; Velar de Irigoyen, "El Estado y la cláusula ...", ob. cit. en nota 75 , p. 949 y siguientes; Spota, "La cláusula compromisoria ...", ob. cit. en nota 78, p. 603 y siguientes. 
Si bien numerosas normas -tales como los tratados internacionales suscriptos por nuestro país y la ley 24.488- han permitido el sometimiento del Estado a arbitraje aún en materias que lo involucran en su carácter de poder público ${ }^{100}$, subsisten todavía ciertas resistencias en la doctrina, vinculadas en general con una visión crítica de los procesos de globalización ${ }^{101}$.

La Corte Suprema no se ha expedido expresamente sobre el punto en épocas recientes ni ha distinguido en detalle hasta el momento según se trate del arbitraje local o internacional. No obstante ello, un reciente pronunciamiento al que nos referiremos más adelante denota una visión restrictiva sobre la jurisdicción arbitral, que ha generado justificadas dudas respecto al futuro del arbitraje en la Argentina ${ }^{102}$.

\section{II.3 La revisión de laudos arbitrales en los que el Estado es parte}

La revisión de laudos dictados en procedimientos arbitrales en los que el Estado es parte no presenta diferencias sustanciales con el sistema aplicable a aquellos laudos dictados en arbitrajes entre particulares.

Por lo general, las decisiones arbitrales son objeto de revisión limitada por parte de los tribunales de justicia en los casos en que (i) la parte vencida interpone un recurso de anulación o

100. El artículo 2 de la ley 24,488 en materia de inmunidad de jurisdicción de estados extranjeros establecen como una excepción a ella los casos en que el Estado "... consienta expresamente a través de un tratado internacional, de un contrato escrito o de una declaración en un caso determinado, que los tribunales argentinos ejerzan jurisdicción sobre ellos". Si el Estado argentino admite la justiciabilidad de un Estado extranjero, sin distinción entre actos iure imperi e iure gestionis, cuando éste presta su expreso consentimiento, igual justiciabilidad en lo que a él respecta deberia aceptar en función del principio de reciprocidad.

101. Ver, entre otros, Rosatti, "Los tratados bilaterales ...", ob. cit. en nota 5, p. 1283 y siguientes; Constante, Liliana B. y Corti, Aristides Horacio, "La soberania y los tribunales arbittales del CIADI", La Ley 2005-C, 1032; Casás, José Osvaldo, "Breves reflexiones -a raiz de una sentencia- sobre el arbitraje internacional y el orden público constitucional", La Ley 2005-A, Il.

102. Ver ași C.S.J.N., "José Cartellone Construcciones Civiles S.A. c/ Hidroeléctrica Norpatagónica S.A. o Hidronor S.A. s/ proceso de conocimiento", Fallos: 327:1881 del 11 de junio de 2004. 
(ii) la parte vencedora en un procedimiento arbitral internacional requiere su reconocimiento en el territorio de un Estado para su posterior ejecución.

\section{II.3.1 La revisión de laudos ante recursos interpuestos por la parte vencida}

Si bien excedería el propósito del presente trabajo realizar un análisis detallado de esta materia, sujeta a las particularidades de cada régimen legal, una primera aproximación al tema requiere en general distinguir entre los laudos dictados en procedimientos arbitrales nacionales y los emitidos en procedimientos arbitrales internacionales.

Arbitrajes nacionales. Los laudos emitidos en arbitrajes nacionales en los que el Estado es parte y tramitados de acuerdo al procedimiento previsto en el Código Procesal Civil y Comercial de la Nación (CPCC) -como, por ejemplo, los que se promuevan en función de lo dispuesto en el artículo 18 de la ley 23.982- se encuentran sujetos a los recursos judiciales establecidos en ese cuerpo normativo.

Al respecto, el artículo 758 del CPCC dispone que de no renunciarse a ellos en el compromiso arbitral, procederán contra el laudo los recursos admisibles respecto de la sentencias de los jueces. A su vez, el artículo 760 establece que la renuncia a los recursos no obstará a la admisibilidad de los de aclaratoria y nulidad ${ }^{103}$. Este tipo de disposiciones indica una tendencia contraria a que el arbitraje se constituya en la instancia única de juzgamiento ${ }^{104}$.

103. El recurso de nulidad de acuerdo a los artículos 760 y 761 del CPCC puede únicamente fundarse en la falta esencial del procedimiento, en haber fallado los ártitros fuera de plazo, en haber fallado sobre puntos no comprometidos o en el hecho que el laudo contenga en la parte dispositiva decisiones incompatibles entre sí. La instancia anulatoria no habilita, así, a revisar el pronunciamiento del tribunal arbitral en cuanto al fondo, su razonabilidad y equidad. En igual sentido, ver, entre otros, Caivano, "Arbitraje", $o b$, citt en nota 8, p. 288 y siguientes.

104. Ver, en igual sentido, Colombo, Carlos J. y Kiper, Claudio M., "Código Procesal Civil y Comercial de la Nación Anotado y Comentado", I, La Ley, $2^{\circ}$ edición, Buenos Aires, 2006, p. 734. 
Por otra parte, los laudos emitidos como consecuencia de procedimientos arbitrales regidos por normas específicas son susceptibles de revisión judicial en la medida y con el alcance que dichas normas dispongan. Tal era el caso, por ejemplo, del procedimiento de arbitraje ante el Tribunal Arbitral de Obras Públicas, hoy disuelto ${ }^{105}$.

En relación a la revisión de laudos arbitrales por parte de tribunales judiciales argentinos, la Corte Suprema de Justicia de la Nación no ha mantenido una posición uniforme.

Como principio general, el alto tribunal ha sostenido que contra "... las decisiones de la jurisdicción arbitral pactada libremente por los interesados" no caben "... otros recursos que los consagrados por las respectivas leyes procesales" 106 y que "... la garantía según la cual todos los habitantes del país gozan del derecho a ocurrir ante un órgano judicial en procura de justicia ... es también renunciable, como se infiere de los precedentes citados y de aquellos en que se resolvió que no puede aducir desconocimiento de principios o garantías constitucionales el particular que, habiendo podido optar entre la vía judicial y la administrativa, elige esta última y, en virtud de ello, contribuye voluntariamente a provocar una decisión irrevisible de la Administración Pública..."107.

105. El Tribunal Aubitral de Obras Públicas creado por decreto 11.511/47 y disuelto por el decreto $1349 / 01$ estaba integrado por dos funcionarios del Estado y un representante de las empresas constructoras. Esta circunstancia había generado cuestionamientos respecto de su calidad de verdadero tribunal arbitral dada la ausencia de independencia de sus miembros tespecto a las partes en conflicto. En atención a ello y al hecho que -como recuerda Bianchi ("El Estado nacional ante el arbitraje", ob. cit. en nota 75, p. 1405)-, el sometimiento al citado tribunal resultaba de carácter obligatorio para el Estado a opción del interesado, los ministros Petracchi y Fayt entendieron en su voto en disidencia en el caso Meller (Fallos: 325:2893) que no podía considerarse a dicho órgano como de naturaleza arbitral, sino una jurisdicción administrativa predispuesta (cons. 23). Como bien recuerda González Campaña ("Desnaturalización del arbitraje administrativo", La Ley, Suplemento de Derecho Administrativo, agosto 2004, p. 8), hasta el caso "Pirelli Cables c. Empresa Nacional de Telecomunicaciones" (Fallos: $322: 298$ del 9 de marzo de 1999) la Corte consideraba que no cabia recurso judicial alguno contra las decisiones de ese tribunal. En fallos posteriores -Aion (29 de agosto de 2000 ) y Meiler ( 5 de noviembre de 2002)- la Corte modificó esa posición al agregar seguidamente a dicha doctrina "... ni se advierte arbitrariedad en la decisión atacada que justijfique la intervención de esta Corte", abriendo así la puerta para la revisión judicial de los laudos de ese tribunal en los supuestos de arbitrariedad.

106. Fallos: 237:392 del 5 de abril de 1957.

107. Fallos: 250:61 del 16 de junio de 1961. 
Sin embargo, en algún precedente, la Corte ha reconocido como obiter dictum la potestad judicial de revisar laudos arbitrales excediendo el ámbito propio de los recursos dispuestos en las normas procesales. Señaló así en Cooperativa Eléctrica y Anexos de General Acha Limitada108 del año 1975 que "... el ejercicio que en cada caso se haga de la jurisdicción arbitral no comporta más atribución que la de juzgar legal y razonablemente dentro de los términos del conflicto; y que si bien la apreciación de los hechos y aplicación regular del derecho es función del árbitro, no excluye que pueda ser impugnada judicialmente la inconstitucionalidad, la ilegalidad o irrazonabilidad en que hubiese incurrido al laudar".

El razonamiento de la Corte evita un examen concreto de los recursos disponibles, atribuyéndose potestades que, en ciertas ocasiones, excederían los límites establecidos a su competencia por la legislación procesal vigente. Bien puede sostenerse que los órganos judiciales son competentes para revisar tanto las cuestiones de fondo consideradas en el laudo como su razonabilidad en los supuestos en que las partes no han renunciado al recurso de apelación, pero semejante razonamiento carece de sustento similar en el caso en que se renunció a ese recurso y únicamente procede el limitado recurso de nulidad por expresa disposición del artículo 760 del CPCC.

Lo cierto es que el obiter dictum señalado dejó latente la posibilidad de que los tribunales judiciales ejercieran un mayor control de los pronunciamientos arbitrales, con independencia de los términos de los recursos previstos normativamente.

En esa senda incursionó el alto tribunal en su conocido pronunciamiento emitido en el caso "Cartellone" del año 2004109.

108. Fallos: 292:223 del 7 de julio de 1975 .

109. Ver así C.S.J.N., "José Cartellone Constnicciones Civiles S.A. c/ Hidroeléctrica Norpatagónica S.A. o Hidronor S.A. s/ proceso de conocimiento", Fallos: 327:1881 del II de junio de 2004 . 
La actora había celebrado un contrato de obra pública en el que se había previsto el sometimiento a arbitraje de cualquier controversia entre comitente y contratista, sujeto a la previa interposición de un reclamo en sede administrativa. Respecto del laudo, se había establecido que él sería definitivo e inapelable.

Habiéndose suscitado reclamos recíprocos que no pudieron resolverse en sede administrativa, las partes recurrieron a arbitraje para dirimir varias de las cuestiones debatidas y ratificaron en el compromiso arbitral la inapelabilidad del laudo.

Cartellone promovió demanda arbitral reclamando diferencias de precio supuestamente adeudadas por Hidronor, más los correspondientes intereses. El tribunal arbitral hizo lugar parcialmente a la demanda, ante lo cual Hidronor dedujo recurso de anulación en los términos de los artículos 760 y 761 del CPCC.

La Sala II de la Cámara Nacional de Apelaciones en lo Civil y Comercial Federal rechazó el recurso por entender que no se encontraban acreditadas las causales previstas en las referidas normas procesales, pues la mayoría de los agravios conducían a que el tribunal examinara la justicia o equidad del pronunciamiento arbitral, lo que no era posible en razón de que las partes habían renunciado a apelarlo. La Cámara sólo se pronunció respecto de la pretensión anulatoria fundada en haber fallado el tribunal arbitral ultra petita al decidir que la actualización de los reclamos de la actora debía efectuarse desde enero de 1985 en contra de lo dispuesto en el compromiso arbitral, en el que -según Hidronor- aquella parte había señalado que las sumas en cuestión estaban actualizadas a febrero del mismo año. La Sala rechazó, asimismo, este agravio.

Contra ese pronunciamiento, Hidronor interpuso recurso ordinario de apelación ante la Corte, el que fue concedido. 
El alto tribunal revocó la decisión de la Cámara, haciendo lugar a la nulidad parcial por ultra petita por entender que los valores reclamados debían ser actualizados desde febrero de 1985. Se comparta o no la decisión sobre el punto, lo cierto es que la Corte tenía competencia para entender en ese agravio específico. Sin embargo, seguidamente, fue más allá de los límites del examen estricto de nulidad a fin de revisar y modificar los intereses aplicados en el laudo para fijar la suma adeudada al 1 de abril de 1991.

Para justificar su intervención en este último punto, ajeno a las causales de anulación establecidas en el CPCC, la Corte recurrió el obiter dictum vertido en Cooperativa Eléctrica y Anexos de General Acha Limitada citado anteriormente y sostuvo que "... no puede licitamente interpretarse que la renuncia a apelar una decisión arbitral se extienda a supuestos en que los términos del laudo que se dicte contrarien el orden público, pues no es lógico prever, al formular una renuncia con ese contenido, que los arbitros adoptarán una decisión que incurra en aquel vicio. Cabe recordar al respecto que la apreciación de los hechos y la aplicación regular del derecho son funciones de los arbitros $y$, en consecuencia, el laudo que dicten será inapelable en esas condiciones pero, en cambio, su decisión podrá impugnarse judicialmente cuando sea inconstitucional, ilegal o irrazonable. Que por aplicación de los principios expuestos, la renuncia formulada por las partes en el contrato y el compromiso no constituye óbice para que esta Corte revoque lo dispuesto en el laudo en cuanto a la aplicación de los intereses (...) [porque] (...) cuando el resultado obtenido se vuelve objetivamente injusto debe ser dejado de lado, en tanto dicha realidad debe prevalecer sobre abstractas fórmulas matemáticas (...) [La] obligación [del deudor] no puede exceder el crédito actualizado con un interés que no trascienda los limites de la moral y las buenas costumbres (arg. arts. 953, 1071 y 21 del Código Civil, Fallos: 318:1345; 320:158), en cuya observancia está interesado el orden público, que ha sido ast vulnerado por la decisión arbitral en cuanto decidió la aplicación al caso de las tasas de interés referidas". 
El pronunciamiento de la Corte ha generado seria preocupación en la doctrina ${ }^{110}$. Las amplias causales invocadas en el fallo importan un preocupante desconocimiento tanto de las previsiones legales aplicables como de los principios fundamentales en la materia, acertadamente reconocidos por la Corte en decisiones anteriores. Suscitan, además, serias dudas respecto a la eficacia práctica del arbitraje como medio alternativo de resolución de conflictos en nuestro país.

La importancia de esta discusión hace suponer que el debate en esta materia dista de encontrarse concluido. No sería de extrañar que, como ha ocurrido en otros países, pronunciamientos como el mencionado impulsen aún más el intercambio de ideas y culminen a mediano plazo con un reconocimiento más firme de la autonomía e importancia del procedimiento arbitral.

Arbitrajes internacionales. En el caso de laudos dictados en procedimientos arbitrales internacionales, las legislaciones nacionales prevén, en general, que los tribunales de la sede del arbitraje cuentan con jurisdicción exclusiva para entender en las acciones de nulidad de laudos, en los términos y condiciones prescriptos por la ley local ${ }^{111}$.

110. Entre otros, ver Morello, Augusto M., "Arbitraje internacional. Proyecciones", La Ley 2005-C, 1222; Marzorati, Osvaldo J., "Constitución Nacional y arbitraje"; Méndez, Héctor O., "Impugnación judjcial de laudos arbitrales. El caso "Cartellone'. Un lamentable retroceso", JA 2005-I-1310; Dioguardi, Juana, "El arbitraje ingresa solapadamente al Poder Judicial", La Ley Suplemento Achualidad del 9 de noviembre de 2004, p. 2.

111. Gaillard y Savage (editores), "Fouchard Gailłatd Goldman ...", ob. cit. en nota 8, pp. 887-888. Resulta interesante destacar la particular posición de la jurisprudencia francesa respecto de la anulación de laudos extranjeros ante los tribunales judiciales de la sede del arbitraje. En Iinea con decisiones emitidas por la Corte de Casación, un reciente pronunciamiento de la Cámara de Apelaciones de Paris del 25 de septiembre de 2005 ha atirmado que los tribunales franceses pueden reconocer un laudo extranjero que ha sido anulado en el pais sede del arbitraje en la medida en que el laudo no resulte inconsistente con la ley francesa. El fundamento de esta decisión es que el fallo del tribunal judicial del lugar de sede del procedimiento arbitral carece de efectos internacionales, toda vez que la decisión de asulación se limita al ejercicio de potestades soberanas en el lugar del arbitraje. Siempre que se pretenda el reconocimiento y ejecución de un laudo en Francia, su validez será determinada por aplicación de la ley francesa. Ver, asi, Cámara de Apelaciones de París, "Direction Générale de L'Aviation Civile de L'Emizat de Dubai y. International Bechtel Co., LLP", decisión de] 29 de septiembre de 2005, Stockholm Intenacional Arbitration Review 2005:3, p. 151, con comentarios de Philippe Pinsolle y Alexis Moutre. Nuestro pais carece de normativa especifica en materia de arbitrajes internacionales, con excepción de la regulación del procedimiento de reconocimiento y ejecución de laudos extranjeros prevista en el CPCC y en tratados internacionales como la Conven- 
No obstante ello, el arbitraje internacional presenta ciertas particularidades que obligan a formular distinciones en función del instrumento que rija el procedimiento. No será idéntico el tratamiento que se dispensará a un laudo dictado al amparo de un tratado internacional que a aquél emitido a la luz de las normas convenidas por las partes o indicadas por las reglas de conflicto de derecho internacional privado.

Así, en el supuesto que el arbitraje fuera conducido de acuerdo a reglas que las propias partes hubieran acordado -por ejemplo, aquéllas previstas por entidades especializadas como la Cámara de Comercio Internacional (CCI) o la American Arbitration Association (AAA)-, el laudo podrá ser objeto de revisión judicial más allá de las renuncias que las partes pudieran haber efectuado. Ello será así en el caso que, por ejemplo, normas de orden público de algún Estado aplicables a un procedimiento arbitral -como el artículo 760 del CPPC argentino en relación con el recurso de nulidad- establezcan la irrenunciabilidad de su impugnación judicial. De allí la importancia que asume la sede del arbitraje en tanto será su legislación la que resultará, por lo general, aplicable a los procedimientos arbitrales tramitados y a los laudos dictados en su ámbito territorial de aplicación ${ }^{112}$.

En cambio, de regirse el procedimiento arbitral por disposiciones contenidas en tratados internacionales, los Estados parte deberán respetar las previsiones que en materia de revisión allí se prevean. En tal sentido, la Convención de Viena sobre el Derecho de los Tratados impide a los Estados parte de un convenio internacional oponer sus normas internas como justificación para su incumplimiento ${ }^{113}$.

ción de Nueva York de 1958, la Convención de Panamá de 1975 y el Convenio CIADI. En consecuencia, resultan aplicables al arbitraje internacional las normas existentes en materia de arbitraje local (CPCC y ordenamientos vigentes) en aquellos supuestos en que éste tenga por sede territorios bajo sus respectivos ámbitos de aplicación.

112. Gaillard y Savage (editores), "Fouchard Gaillard Goldman ...", ob, cit, en nota 8, p. 645.

113 Dispone asi el articulo 27 de la Convención de Viena sobre el Derecho de los Tratados que "una parte no podrá invocar las disposiciones de su derecho intemo como justificación del incumplimiento de un tratado ...".

132 Revista Ecuatoriana de Arbitraje 
El Convenio CIADI constituye un ejemplo de tratado internacional que contempla normas específicas sobre revisión de laudos. De conformidad con sus disposiciones, los laudos emitidos en procedimientos regidos por dicho tratado son obligatorios para las partes y no pueden ser objeto de apelación o cualquier otro recurso, excepto los de revisión, anulación y aclaración ante el mismo tribunal arbitral o un tribunal ad-hoc constituido por el CIADI, según el recurso interpuesto. En función de ello, los laudos emitidos conforme al Convenio CIADI no son susceptibles de revisión por parte de los tribunales nacionales ${ }^{114}$.

\section{II.3.2 Reconocimiento de laudos arbitrales}

En caso de incumplimiento, los laudos arbitrales extranjeros condenatorios contra el Estado se hallan, por lo general, sujetos a un proceso de reconocimiento previo a su ejecución judicial. Por el contrario, los laudos condenatorios locales resultan ejecutables directamente, de acuerdo con las normas en materia de ejecución de sentencias contra el Estado.

A fin de encuadrar adecuadamente las diferencias, corresponde referirse brevemente, por un lado, a los conceptos de arbitraje internacional y laudo internacional y, posteriormente, a los de reconocimiento y ejecución.

114. Ciertos autores han cuestionado el sistema establecido en el Convenio CIADI por considerarlo contrario a la Constitución Nacional. Ver, así, entre otros, Rosatti, "Los tratados bilaterales ...", ob. cit. en nota 5, p. 1283 y siguientes; Constante y Corti, "La soberanía y los tribunales ...", ob. cit en nota 10I, p. 1032 y siguientes; Casás, "Breves reflexiones ...", ob. cit. en nota I01, p. 11 y siguientes. La posición señalada se encuentra relacionada a consideraciones políticas cuyo examen excedería el limitado ámbito de este trabajo. Basta advertir aquí que el citado convenio no cercena todo control de constitucionalidad. Lo único que prohíbe es la revisión de los laudos dictados en procedimientos arbjtrales tramitados en su ámbito. El Estado mantiene la posibilidad de denunciar el Convenio y aún de efectuar un examen de constitucionalidad de sus disposiciones, asi como las de los tratados bilaterales de inversión en procesos judiciales ante los tribunales argentinos, siempre que ello no implicgue la revisión ni el desconocimiento de los laudos. Los mencionados cuestionamientos parecen no advertir que una intervención como la pretendida no sólo importaría una violación del Convenjo CIADI que privaria de todo sentido práctico al mecanismo arbitral alli previșto sino, también, el desconocimiento de lo dispuesto en el artículo 27 de la Convención de Viena sobre el Dereche de los Tratados. 
Arbitraje internacional y laudo internacional. A los efectos del reconocimiento de laudos, las legislaciones no equiparan al arbitraje internacional con el laudo extranjero o internacional. Un arbitraje puede ser internacional y su laudo ser considerado de carácter local. A diferencia de los parámetros para definir la internacionalidad del arbitraje que van desde el domicilio de las partes hasta la transnacionalidad de las cuestiones vinculadas al acuerdo arbitral, los criterios para definir la "nacionalidad" de un laudo son, por lo general, dos: la sede del arbitraje o la ley que rige el procedimiento ${ }^{115}$.

La Convención de Nueva York de 1958 sobre el Reconocimiento y Ejecución de las Sentencias Arbitrales Extranjeras no establece un criterio uniforme, aunque se inclina principalmente por el de la sede del arbitraje. Su ámbito de aplicación se extiende a todos los laudos extranjeros, considerando por tales a todos aquellos que se dicten en un Estado diferente de aquél donde se solicita su reconocimiento y ejecución ${ }^{116}$. Sin embargo, a fin de contemplar la diversidad existente en la materia, dispone seguidamente que ella será también aplicable a los laudos que -aún cuando hayan sido emitidos en el país donde se requiere su reconocimiento y ejecución- no sean considerados como "nacionales" por aplicación de un criterio diferente para definir la nacionalidad del laudo de acuerdo con lo previsto en la ley local ${ }^{117}$.

115. Ver Gaillard y Savage (editores), "Fouchard Gaillard Goldman ...", ob. cit. en nota 8, pp. 652-653; Redfern y Hunter, "Law and practice ...", $o b$, cit. en nota 23, pp. 447-448; Caivano, "Arbitraje", $o b$. cit. en nota 8, pp. 322-323.

116. Ver Tawil, Guido Santiago y Zuleta Jaramillo, Eduardo (Directores), "El arbitraje comercial internacional. Estudio de la Convención de Nueva York con motivo de su $50^{\circ}$ aniversario", Abeledo Perrot, Buenos Aires, 2008; Gaillard y Savage (editores), "Fouchard Gaillard Goldman ...", ob. cit. en nota 8, p. 966.

117. Ibid., pp. 966-967. El articulo 1(1) de la Convención de Nueva York establece que ella "... se aplicará al reconocimiento y la ejecución de las sentencias arbitrales dictadas en el territorio de un Estado distinto de aquél en que se pide el reconocimiento y la ejecución de dichas sentencias, y que tengan su origen en diferencias entre personas naturales o juridicas. Se aplicará también a las sentencias arbitrales que no sean consideradas como sentencias nacionales en el Estado en el que se pide su reconocimiento y ejecución".

134 Revista Ecinaioriana de Arbitraje 
De ese modo autoriza a los Estados que no definen la nacionalidad de los laudos a partir del criterio de la sede, sino del de la ley procesal, a aplicar la convención a laudos que no obstante haberse dictado en su territorio se hubieran regido por una ley procesal distinta a la local.

Reconocimiento y ejecución. El reconocimiento de un laudo consiste en su aceptación como título válido susceptible de ser ejecutado en el territorio del Estado. Tal reconocimiento se obtiene, por lo general, a través del procedimiento de exequátur. En el ámbito nacional, el procedimiento aplicable a los laudos arbitrales se encuentra regulado en el artículo 519 bis del CPCC y en diferentes convenciones internacionales ${ }^{118}$.

La ejecución es, en cambio, la actividad jurisdiccional instada a petición de parte para obtener el cumplimiento forzoso de los términos del laudo ${ }^{119}$.

Si bien no existe un régimen uniforme en la legislación interna de los países en materia de reconocimiento de laudos arbitrales extranjeros, la Convención de Nueva York de 1958 -ratificada a la fecha por 137 naciones $^{120}$ - ha aportado cierta homogeneidad y permite extraer algunos principios generales.

118. Ver, al respecto, la Convención de Nueva York de 1958 sobre el Reconocimiento y Ejecución de las Sentencias Arbitrales Extranjeras (aprobada por ley 23.619), el Tratado de Derecho Procesal Internacional de Montevideo de 1940 (aprobado por decreto-ley 7771/56), la Convención Interamericana sobre Eficacia Extraterritorial de Sentencias y Laudos Árbitrales Extranjeros (CIDIP II, aprobada por ley 22.921), la Convención Interamericana sobre Arbitraje Comercial Internacional (aprobada por ley 24.322) y el Convento CIADI (aprobado por ley 24.353).

119. Bien se ha señalado que corresponde diferenciar "... dos conceptos en relación a la eficacia extratemitorial el reconocimiento implica aceptación, por la autoridad requerida, de wn derecho consagrado por la sentencia extranjera; la ejectción, por su parte, importa exigir por internedio del juez la satisfacción material del derecho consagrado en la sentencia extranjera. Sin embargo, no hay ejecución sin reconociniento, pero sí a la inversa. Las sentencias declarativas y las consitiutivas sólo son objeto de reconocimiento, en cambio poseerán eficacia ejecutoria las de condena, siendo este efecto imperativo, el caso más común de la invocación de tuna decisión foránea". Ver Colombo y Kiper, "Código Procesal ...", IV, ob. cit. en nota 104, p. 557.

120. Ver http://www.uncitral.org/uncitral/es/uncitral_texts/arbitration/NYConvention_status.html (última visita 13 de agosto de 2006). La República Argentina ratificó la Convención de Nueva York el 14 de marzo de 1989, entrando ella en vigor para nuestro pais et 12 de junio de ese misno año. 
El procedimiento de reconocimiento de un laudo extranjero o internacional no constituye una oportunidad para que los tribunales judiciales locales -generalmente la autoridad competente en materia de exequátur efectúen una revisión plena de lo resuelto por el tribunal arbitral. Su objeto es más limitado. Consiste en verificar la competencia del órgano arbitral, si se ha observado la garantía del debido proceso en el procedimiento arbitral; si el laudo no viola el orden público de acuerdo a las reglas vigentes en el país (requisitos intrínsecos) y si el laudo cumple con las exigencias de legalización y autenticación (requisitos extrínsecos) ${ }^{121}$.

121. Ver Palacio, Lino Enrique, "Derecho Procesal Civil", VII, Abeledo-Perrot, Buenos Aires, 1994, pp. 313-314. En rẹlación con los requisitos extrínsecos, la Convención de Nueva York de 1958 establece que la parte que solicite el reconocimiento de un laudo arbitral deberá presentar conjuntamente con la demanda (i) el otiginal debidamente autenticado del laudo o una copia de ese oríginal que reúna las condiciones requeridas para su autenticidad, (ii) el original del acuerdo de arbitraje por escrito, bajo el cual se sometió la controversía a arbitraje y (iii) una traducción certificada por un traductor oficial o un traductor jurado, 0 por agente diplomático 0 consular del laudo al idioma oficial del pais en el que se pretende su reconocimiento en el caso que no se correspondiera con el idioma en que se encuentra redactado (articulo 4 de la Convención de Viena de 1958). Respecto de los requisitos extrínsecos, el reconocimiento de un laudo podrá negarse únicamente si la parte contra la cual se pretende el reconocimiento prueba ante la autoridad competente que: (i) las partes del acuerdo arbitral estaban sujetas a alguna incapacidad en virtud de la ley que les es aplicable o que dicho acuerdo no es válido en virtud de la ley a que las partes lo han sometido, o si nada se hubiera indicado a este res. pecto, en virtud de la ley del pais en que se haya dietado la sentencia; o (ii) la parte contra la cual se invoca el laudo no ha sido debidamente notificada de la designación del árbitro o del procedimiento de arbitraje o no ha podido, por cualquier otra razón, hacer valer sus medios de defensa; o (iii) el laudo se refiere a una diferencia no prevista en el compromiso o no comprendida en las disposiciones de la cláusula compromisoria, o contiene decisiones que exceden de los términos dcl compromiso o de la cláusula compromisoria; o (iv) la constítución del tribunal arbitral o el procedimiento arbitral no se han ajustado al acuerdo celebrado entre las partes 0 , en defccto de tal acuerdo, que la constitución del tribunal arbitral o el procedimiento arbitral no se han ajustado a la ley del país donde se ha efectuado el arbitraje; $O$ (v) la sentencia no es aún obligatoria para las partes o ha sido anulada 0 suspendida por una autoridad competente del pais en que, o conforme a cuya ley, ha sido dictads esa sentencia (artículo 5.1 de la Convención de Nueva York). La Convención prevé también que se podrá negar el reconocimiento de un laudo arbitral si la autoridad competente ante quien se solicita el reconocimiento comprueba que: (i) de acuerjo con la legislación del pais el objeto de la diferencia no es susceptible de solución por vía de arbitraje; o (ii) el reconocimiento del laudo sería contrarios al orden público del pais (artículo 5.2 de la Convención de Nueva York). El CPCC argentino prevé un procedimiento similar, apjicable a aquellos laudos provenientes de un pajs que no se encuentre vinculado con la República Argentina por un tratado en la materia. El articulo 519 Bis del CPCC dispone asi que "los laudos pronunciados por tribunales arbitrales extranjeros podrán ser ejecutados por el procedimiento establecido en los articulos anteriores, siempre que: 1) Se cumplieren los recaudos del artículo 517, en lo pertinente $y$, en su caso, la prórroga de jurisdicción hubiese sido admisible en los términos del articulo 1. 2) Las cuestiones que hayan constituido el objeto del compromiso no se encuentren excluidas del arbitraje conforme a lo establecido por el artículo $737^{\prime \prime} . \Lambda \mathrm{su}$ vez, el articulo 517 establece: "Las sentencias de tribunales extranjeros tendrán fuerza ejecutoria en los términos de los tratados celebrados con el país de que provengan. Cuando no htbiese tratados, serán ejecutables si concurriesen los siguientes requisitos: I) Que la sentencia, con autoridad de cosa juzga- 
Si bien los procedimientos de exequátur tienen amplia recepción tanto en el derecho argentino como comparado, el reconocimiento no constituye en todos los supuestos un requisito ineludible para la posterior ejecución del laudo. No procede el exequátur, por ejemplo, en casos en que un tratado internacional disponga que el laudo arbitral internacional o extranjero será reconocido automáticamente en los Estados parte. Tal es el caso del Convenio CIADI que establece un sistema autónomo y prácticamente automático de reconocimiento de los laudos dictados bajo sus reglas ${ }^{122}$.

En función de ello, el reconocimiento de dichos laudos en los Estados parte del Convenio está sujeto únicamente al cumplimiento de ciertos requisitos extrínsecos ${ }^{123}$, no correspondiendo sujetar su reconocimiento a un análisis de su adecuación con las normas internas de los Estados ${ }^{124}$.

da en el Estado en que se ha pronunciado, emane de tribunal competente según las normas argentinas de jurisdicción internacional y sea consecuencia del ejercicio de una acción personal o de una acción real sobre un bien mueble, si éste ha sido trasladado a la República durante o después del juicio tramitado en el extranjero. 2) Que la parte demandada contra la que se pretende ejecutar la sentencia hubiese sido personalmente citada y se haya garantizado su defensa. 3) Que la sentencia retina los requisitos necesarios para ser considerada como tal en el lugar en que hubiere sido dictada y las condiciones de autenticidad exigidas por la ley nacional 4) Que la sentencia no afecte los principios de orden público del derecho argentino. 5) Que la sentencia no sea incompatible con otra pronunciada, con anterioridad o simulitineamente, por un tribunal argentino".

122. Dispone asi eł articulo 54 del citado convenio: "Todo Estado Contratante reconocerá al laudo dictado conforme a este Convenio carácter obligatorio y hará ejecutar dentro de sus territorios las obligaciones pecuniarias impuestas por el laudo como si se tratare de una sentencia firme dictada por un tribunal existente en dicho Estado (...)".

123. El artículo 54(2) del Convenio CIADI establece así como único requisito para el reconocimiento de un laudo la presentación de una copia debidamente certificada por el Secretario General ante los tribunales competentes 0 ante cualquier otra autoridad designada por los Estados Contratantes a ese efecto.

124. Schreuer, Cluristoph, "The ICSID Convention: A Commentary", Cambridge University Press, Cambridge, 2001, pp. 1115, 1127-1131. 


\section{II.4 Ejecución judicial de laươos arbitrales contra el Estado}

\section{II.4.1 La ejecución en el territorio del Estado parte de la controversia}

La ejecución judicial de laudos contra el Estado en su propio territorio se encuentra sujeta al procedimiento allí vigente en materia de ejecución de sentencias contra el Estado.

Este principio resulta de aplicación aún en el supuesto de laudos emitidos conforme al Convenio CIADI. En tal sentido, su artículo 54(3) dispone que "el laudo se ejecutará de acuerdo con las normas que, sobre ejecución de sentencias, estuvieren en vigor en los territorios en que dicha ejecución se pretenda".

\section{II.4.2. Ejecución de laudos contra el Estado en territorio de otro Estado}

El régimen aplicable adquiere mayor complejidad cuando se pretende la ejecución de un laudo no ya en el territorio del propio Estado, sino en otro país. En estos casos, el Estado vencido puede invocar su inmunidad de ejecución ${ }^{125}$.

El consentimiento del Estado al arbitraje no importa necesariamente que éste se vea imposibilitado de oponer su inmunidad de ejecución una vez dictado el laudo cuando se pretenda su cumplimiento forzado en la jurisdicción de otro Estado ${ }^{126}$. En este sen-

125. Al respecto, por ejemplo, el Convenio CIADI establece en su articulo 55 en materia de ejecución de laudos contra un Estado en territorio de otro Estado que "nada de lo dispuesto en el Articulo 54 se interpretará como derogatorio de las leyes vigentes en cualquier Estado Contratante relativas a la inmunidad en materia de ejecución de dicho Estado o de otro Estado extranjero".

126. Sobre la inmunidad de ejecución de los Estados, ver, entre otros, Schrever, Christoph, "State immunity: Some Recent Developments", Grotious, Cambridge, 1988; Schreuer, "The ICSID Convention ...", oh. cit. en nota 124, p. 1141 y siguientes; Remiro Brotóns, Antonio; Riquelıne Cortado, Rosa M.; Orihuela Calatayud, Esperanza; Diez-Hochleitner, Javier y Pérez-Prat Durbán, Luis, "Derecho Internacional", McGraw-Hill, Madrid, 1997, p. 816 y siguientes; Brownlie, Ian, "Principles of Public International Law", Oxford University Press, $5^{\circ}$ edición, Oxford, 1998, pp. 346-347; Conforti, Benedetto, "Derecho Internacional", Zavalia, Buenos Aires, 1995, p. 302 y siguientes; Diez de Velasco, Manuel, "Instituciones de Derecho Internacional Público", Tecnos, $13^{\circ}$ edición, Madrid, 
tido, la posición todavía mayoritaria es que la renuncia a la inmunidad de jurisdicción que implica dicho consentimiento no trae aparejada similar renuncia a la inmunidad de ejecución ${ }^{127}$.

La distinción entre una y otra especie de inmunidad responde a las mayores reservas que los Estados en general oponen a la ejecución de sus bienes y al consecuente impacto negativo que ello puede producir en la comunidad internacional ${ }^{128}$.

A diferencia de lo que ocurría algún tiempo atrás, la codificación internacional, las legislaciones nacionales y la jurisprudencia han avanzado a un punto tal que ya no puede afirmarse en la actualidad que exista una regla de derecho internacional que avale una inmunidad de ejecución absoluta de los Estados 129 .

2001, p. 274 y siguientes; González Campos, Sánchez Rodríguez, Sáenz de Santa Maria: "Curso de Derecho Internacional Público", ob. cit. en nota 38, p. 443 y siguientes; Pastor Ridruejo, José A., "Curso de Derecho Internacional Púbblico y Organizaciones Internacionales", Tecnos, $8^{\circ}$ edición, Madrid, 2001, p. 525 y siguientes; Barboza, Julio, "Derecho Internacional Público", Zavalía, Buenos Ajres, 1999 , p. 334.

127. En este sentido, la Convención de las Naciones Unidas sobre las inmunidades jurisdiccionales de los Estados y de sus bienes establece en su artículo 20 que "Cuando se requiera el consentimiento para la adopción de medidas coercitivas de conformidad con los artículos 18 y 19. el consentimiento para el ejercicio de jurisdicción en virtud del articulo 7 no implicará consentimiento para adoptar medidas coercitivas".

128. Ver, entre otros, Remiro Brotóns, Riquelme Cortado, Orihuela Calatayud, Diez-Hochleitner y PérezPrat Durbán, "Derecho Internacional", ob. cit. en nota 126, pp. 816-817; Diez de Velasco, "Instituciones de Derecho Internacional Público", ob. cit. en nota 126, pp. 274-275; Brownlie, "Priticiples of Public International Law", ob. cit. en nota 126, p. 346.

129. Pastor Ridruejo, "Curso de Derecho Internacional Público ...", ob. cit. en nota 126, p. 526. Ello no obsta, por cierto, a que todavia subsistan algunas normas en ese sentido. Entre ellas, cabe mencionar a la Convención Europea sobre inmunidad de los Estados de 1972 -ratificada únicamente por oclso estađos-al prever una inmunidad absoluta de ejecución. Sólo exceptúa tal inmunidad en la medida que el Eștado renuncie a ella por escrito en un caso particular. El artícuło 23 de dicha convención establece que: "No meastures of execution or preventive measures against the property of a Contracting State may be taken in the territory of another Contracting State except where and to the extent that the State has expressty consented thereto in writing in any particular case". No obstante ello, su articulo 24 faculta a los Estados a declarar mediante notificación al Secretario General del Consejo de Europa que sus tribunales tendrán competencia para sustanciar procedimientos contra un. Estado parte en la medida en que también posean competencia para sustanciar procedimientos contra Estados no parte de la convención. Aclara el artículo que dicha declaración no afectará la inmunidad de jurisdicción de la que gozan los Estados en relación a sus actos iure imperit. En el caso en que el Estado donde se pretende la ejecución de un laudo y el Estado contra el cual se pretende dicha ejecución hayan formulado la referida declaración, la Convención establece en su artículo 26 que los pronunciamientos emitidos contra este último relacionados con actividad industrial o comercial, en la cual el Estado participe en calidad de persona privada, pueden ser ejecutados en el territorio del primero 
Diversos han sido los criterios esbozados con el objeto de atenuar esa concepción.

Para una primera posición, la inmunidad de jurisdicción se encontraría en relación directa con la inmunidad de ejecución, de modo tal que no podría un Estado oponer esta última en aquellos casos en que, de acuerdo con la legislación del país en que se pretende la ejecución, no gozaría de inmunidad de jurisdicción en el caso concreto ${ }^{130}$.

Para otros, el consentimiento del Estado al arbitraje debería entenderse como una renuncia implícita a la inmunidad de ejecución ${ }^{131}$.

El criterio predominante en la actualidad es, sin embargo, el que centra su atención en la naturaleza de los bienes sobre los cuales se pretende la ejecución. Por ello, más que debatirse la existencia o inexistencia de una inmunidad absoluta en la materia, prevalece la distinción entre aquellos bienes susceptibles o no de ejecución (inmunidad relativa) ${ }^{132}$. En este sentido, la mayor parte de los cuerpos normativos estatales e internacionales admiten la ejecución de bienes de un Estado extranjero en los casos en que ellos no se encuentren afectados a una función pública ${ }^{133}$, distinguiendo entre bienes comerciales y no comerciales de los Estados ${ }^{134}$.

sobre los bienes contra los cuales el pronunciamiento fue emitido, utilizados exclusivamente en relación con dicha actividad. El artículo 26 de la convencjón dispone ași: "a judgment rendered against a Contracting State in proceedings relating to an industrial or commercial activity, in which the State is engaged in the same manner as a private person, may be enforced in the State of the forum against property of the State against which judgmemt has been given, used exclusively in connection with such an activity, if: a. both the State of the forum and the State against which the judgment has been given have made declarations under Article $24(\ldots)$ ".

130. La inexistencia de inmunidad de este sentido no alcanzaria a todos los bienes del Estado ejecutado, sino generalmente a aquellos que pudieran ser calificados de comerciales. Esta teoria ha tenido recepción aislada en algunos precedentes de los triburales suizos y alemanes. Ver, al respecto, Schrever, "The ICSID Convention ...", ob. cit. en nota 124, p. 1148.

131. Ibid., p. 1149.

132. Remiro Brotóns, Riquelme Cortado, Orihuela Calatayud, Diez-Hochleitner y Pérez-Prat Durbán, "Derecho Internacional", $a b$, cit. en nota 126, p. 817.

133: Conforti, "Derecho Internacional", ob. cit. en nota 126, p. 302; Gaillard y Savage (editores), "Fouchard Gaillard Goldman ...", ob. cit. en nota 8, p. 393.

134. La aplicación de esta regla y los criterios de distinción entre la diversa clase de bienes no es, por cierto, uniforme en el derecho comparado. Ver, entre otros, Schreuer, "The ICSID Convention ...", $o b$. cit en nota 124, pp. 1149-1150. Como sostiene este autor, para la calificación de los bienes en comerciales o no comerciales en materia de inmunidad de ejecución se aplica el criterio de la finalidad del bien, aunque su origen es también tenido en cuenta en algunos casos (Jbid., p. 1160). 
Ratificando esta tendencia, la Asamblea General de las Naciones Unidas aprobó el 2 de diciembre de 2004 la Convención sobre las inmunidades jurisdiccionales de los Estados y de sus bienes 135 , cuyo preámbulo expresa la intención de armonizar la práctica en la materia considerando, asimismo, la evolución que los Estados han experimentado en el ámbito de la inmunidad soberana ${ }^{136}$.

La Convención reconoce como principio general el de la inmunidad soberana de los Estados ${ }^{137}$. Sin embargo, lejos de atribuirle un carácter absoluto, se adscribe en la tendencia más moderna al adoptar una visión restringida del instituto. En materia de ejecución, dispone la improcedencia de medidas coercitivas contra los bienes de un Estado con excepción de los casos en que el Estado preste su consentimiento, haya asignado o destinado bienes a la satisfacción de la demanda objeto de ese proceso, o se determine que los bienes se utilizan específicamente o se destinan a su utilización por el Estado para fines distintos de los fines oficiales no comerciales, que se encuentran en el territorio del Estado del foro y tengan un nexo con la entidad contra la cual se haya incoado el proceso ${ }^{138}$.

135. A/RES/59/38. Su artículo 28 declara que quedará abjerta a la firma de todos los Estados hasta el 17 de enero de 2007 en la Sede de las Naciones Unidas en Nueva York.

136. El preámbulo de la convención expresa:

"Los Estados Partes en la presente Convención,

Considerando que las inmunidades jurisdiccionales de los Estados y de sus bienes constituyen un principio generalmente aceptado en el derecho internacionat consuetudinario,

Teniendo presentes los principios de derecho internacional consagrados en la Carta de las Naciones Unidas,

Considerando que tha convención internacional sobre las inmunidades jurisdiccionales de los Estados y de sus bienes fortaleceria la preeminencia del derecho y la seguridad juridica, particularmente en las relaciones de los Estados con las personas naturales o juridicas, $y$ contribuiria a codificar y desarrollar el derecho internacional y a armonizar la práctica en este ámbito,

Teniendo en cuenta la evolución de la práctica de los Estados respecto de las inmunidades jurisdiccionales de los Estados y de sus bienes,

Afirmando que las normas del derecho internacional consuetudinario seguirán rigiendo las cuestiones que no estén reguladas por lo dispuesto en la presente Convención. Han convenido en lo siguiente:"

137. El artículo 5 de la Convención establece: "Todo Estado goza, para si y sus blenes, de Inmunidad de jurisdicción ante los tribunales de otro Estado, según lo dispuesto en la presente Convención".

138. El artículo 19 prescribe: "No podrán adopiarse contra bienes de un Estado, en relación con un proceso ante un tribunal de otro Estado, medidas coercitivas posteriores al fallo como el embargo y lo ejecución, sino en los casos y dentro de los limites siguientes: a) cuando el Estado haya consentido expresamente en la adopción de tales medidas, en los términos indicados: i) por acuerdo internacio- 
En línea con esa visión restringida de la inmunidad de ejecución, la State Immunity Act de 1978 del Reino Unido reconoce como principio general la inmunidad de ejecución de los Estados extranjeros, sujeta a ciertas excepciones ${ }^{139}$. Entre estas últimas, autoriza la ejecución de bienes que sean utilizados o destinados a ser utilizados para propósitos comerciales ${ }^{140}$.

Un régimen similar establece la Foreign Sovereign Immunities Act de 1976 de los Estados Unidos. Luego de establecer como principio general la inmunidad de ejecución de los Estados extranjeros ${ }^{141}$, admite como excepción a ella el embargo o ejecución de bienes situados en los Estados Unidos y utilizados para una actividad comercial en dicho país, mediando pronunciamiento de un tribunal judicial de los Estados Unidos o alguno de sus estados, en el supuesto que, entre otras condiciones, (i) el Estado extranjero haya renunciado a su inmunidad, o (ii) Ios

nal; ii) por un acuerdo de arbitraje o en wn contrato escrito; o iii) por una declaración ante el tribunal o por una comunicación escrita después de haber surgido una controversia enire las partes; o b) cuando el Estado haya asignado o destinado bienes a la satisfacción de la demanda objeto de ese proceso; o c) cuando se ha determinado que los bienes se utilizan especificamente o se destinant a su utilización por el Estado para fines distintos de los fines oficiales no comerciales y que se encuentran en el territorio del Estado del foro, si bien únicamente podrán tomarse medidas coercitivas posteriores al fallo contra bienes que tengan un nexo con la entidad contra la cual se haya incoado el proceso".

139. Articulo 13(2)(b) de la State Immunity Act de 1978: "the property of a State shall not be subject to any process for the enforcement of a judgment or arbitration award or, in an action in rem, for its arrest, detention or sale".

140. Articulo 13(4) de la State Immunity Act de 1978: "Subsection (2)(b) above does not prevent the issue of any process in respect of property which is for the time being in use or intended for use for com. mercial purposes". También dispone esa ley que si el Estado ha acordado por escrito someter una disputa existente o que pudiera surgir, a arbitraje, el Estado no tiene inmunidad respecto de los procedimientos ante los tribunales del Reino Unido relacionados con el arbitraje. Articulo 9 de la State Immunity Act de 1978: "(1) Where a State has agreed in writing to submit a dispute which has arisen, or may arise, to arbitration, the State is not immune as respects proceedings in the courts of the United Kingdom which relate to the arbitration. (2) This section has effect subject to any contrary provision in the arbitration agreement and does not apply to any arbitration agreement between States". La norma parece referirse exclusivamente a la inmunidad de jurisdicción y difícilmente pueda considerarse que se extiende a la renuncia de la inmunidad de ejecución. En Francia y Alemania, los tribunales han adoptado un enfoque similar y la ejecutabilidad de bienes de un Estado extranjero dependerá de la actividad comercial o gubernamental a la que ellos se encuentren afectados. Ver Schreuer, "The ICSID Convention ...", ob. cit. en nota 124, pp. 1156-1168.

141. Articulo 1609 de la Foreign Sovereign Immunities Act de 1976: "Subject to existing intemational agreements to which the United States is a party at the time of enactment of this Act the property in the United States of a foreign state shall he immune from attachment arrest and execution except as provided in sections 1610 and 1611 of this chapter".

142 Revista Ecuatoriana de ArBitraje 
bienes sean o hayan sido utilizados para una actividad comercial sobre la que se funda el reclamo, o (iii) el pronunciamiento se funde en una orden confirmatoria de un laudo arbitral dictado contra un Estado extranjero, siempre que el embargo o la ejecución misma no resulte inconsistente con disposición alguna del acuerdo arbitral ${ }^{142}$. En líneas generales, de acuerdo con los términos de la legislación norteamericana, resulta más sencillo ejecutar un laudo arbitral que una sentencia contra un Estado

142. El articulo 1610 de la Foreign Sovereign Immunities Act de 1976 establece: "( $a$ ) The property in the United States of a foreign state, as defined in section $1603(a)$ of this chapter, used for a commercial activity in the United States, shall not be immune from attachment in aid of execution, or from execution, upon a judgment entered by a court of the United States or of a State after the effective date of this Act, if - (1) the foreign state has waved its immunity from attachment in aid of execution or from execution either explicitly or by implication, nowithstanding any withdrawal of the waiver the foreign state may purport to effect except in accordance with the terms of the waiver, or (2) the property is or was used for the commercial activity upon which the claim is based, or (3) the exectution relates to a judgment establishing rights in property which has been taken in violation of internationat law or which has been exchanged for property taken in violation of international law, or (4) the execution relates to a judgment establishing rights in property $-(A)$ which is acquired by succession or gift, or (B) which is immovable and situated in the United States: Provided, That such property is not used for purposes of maintaining a diplomatic or consular mission or the residence of the Chief of such mission, or (5) the property consists of any contractual obligation or any proceeds from such a contractual obligation to indemnify or hold harmless the foreign state or its employees under a policy of automobile or other liability or casualty insurance covering the claim which merged into the judgment, or (6) the judgment is based on an order confirming an arbitral award rendered against the foretgn state, provided that attachment in aid of execution, or execution, would not be inconsistent with any provision in the arbitral agreement. (b) In addition to subsection (a), any property in the United States of an agency or instrumentality of a foreign state engaged in commercial activity in the United States shall not be immune from attachment in aid of execution, or from execution, upon a judgment entered by a court of the United States or of a State after the effective date of this Act. if - (I) the agency or instrumentality has waived its immunity from attachment in aid of execution or from execution either explicitly or implicitly, notwithstanding any withdrawal of the waiver the agency or instrumentality may purport to effect except in accordance with the terms of the waiver, or (2) the judgment relates to a claim for which the agency or instrumentality is not immune by virtue of section 1605(a) (2), (3), or (5), or 1605(b) of this chapter, regardless of whether the property is or was used for the activity upon which the claim is based. (c) No attachment or execution referred to in subsections (a) and (b) of this section shall be permitted until the court has ordered such attachment and execution after having determined that a reasonable period of time has elapsed following the entry of judgment and the giving of any notice required under section 1608(e) of this chapter (d) The property of a foreign state, as defined in section 1603(a) of this chapter, used for acommercial activity in the United States, shall not be immune from at achment prior to the entry of judgment in any action brought in a court of the United States or of a State, or prior to the elapse of the period of time provided in subsection (c) of this section, if - (1) the foreign state has explicitly waived its immunity from attachment prior to judgment, notwithstanding any withdrawal of the waiver the foreign state may purport to effect except in accordance with the terms of the waiver, and (2) the purpose of the attachment is to secure satisfaction of a judgment that has been or may ultimately be entered against the foreign state, and not to obtain jurisdiction. (e) The vessels of a foreign state shall not be immune from arrest in rem, interlocutory sale, and execution in actions brought to foreclose a preferred mortgage as provided in section 1605(d)". 
extranjero. Mientras que respecto a estas últimas, el ejecutante deberá muy probablemente acreditar una vinculación especial entre el reclamo objeto de la sentencia y los bienes de carácter comercial a ejecutar conforme al punto (ii) arriba descrito ${ }^{143}$, tal requisito adicional no es aplicable para admitir la ejecución de laudos arbitrales ${ }^{144}$.

No existen disposiciones en el derecho interno argentino en materia de inmunidad de ejecución ${ }^{145}$. Como lo ha reconocido la propia Corte Suprema de Justicia de la Nación en el caso Blasson "...no existe en nuestro país una norma de derecho interno que regule especificamente el conflicto de inmunidad de ejecución de los estados extranjeros suscitado en la causa. La ley 24.488 sólo regula la inmunidad de jurisdicción sin que exista ningún atisbo en su articulado que permita aplicarla por analogía a la inmunidad de ejecución, que a todas luces no ha sido contemplada en aquella ley. En tales condiciones, el caso deberá ser resuelto según las normas y principios del derecho internacional que resulta incorporado ipso iure al derecho argentino federal, pues el desconocimiento de las normas que rigen las relaciones diplomáticas internacionales no tendría otro desenlace que conducir al aislamiento de nuestro pais en el concierto de las naciones" ${ }^{\prime 46}$.

Tras distinguir entre inmunidad de jurisdicción e inmunidad de ejecución ${ }^{147}$, la Corte dejo entrever en esa ocasión su eventual

143. Ello será así en el supuesto en que la situación de quien pretenda la ejecución de una sentencia judjcial no encuadre en ninguna de las restantes condiciones a modo de excepción dispuestas en el articulo 1610 de la Foreign Sovereign Immunities Act de 1976.

144. Ver Schreuer, "The ICSID Convention ...", ob. cit. en nota 124, p. 1153

145. Para un análisis de la inmunidad soberana en la jurispnudencia de nuestra Corte Suprema, ver RabbiBaldi Cabanillas, Renato, "Las inmunidades de jurisdicción y de ejecución en la actual jurisprudencia de la Corte Suprema de Justicta de la Argentina", en Garcia, Márcio y Antenor Pereira Madruga Filho, "A imunidade de jurisdiçao e o Judiciário brasileiro", CEDI (Centro de Estudios de Direito Internacional), Brasilia, Brasil, 2002, pp. 105-128.

146. Fallos: 322:2399. Ver, asimismo, Fallos: 324:1648 del 12 de mayo de 2001 ("Obras Sanitatias de la Nación v. Embajada de la URSS - Representación Comercial de Rusia"). En este último caso, la Corte Suprema ratificó que "... la cuestión relativa a la inmunidad de ejecución (...) no ha sido regulada por la ley $24.488^{\prime \prime}$ (Cons. 10). Para un análisis de los casos Blasson y OSN, ver Rabbi-Baldi Cabanillas, "Las inmunidades de jurisdicción y de ejecución ...", ob. cit. en nota 145, pp. 105-128.

147. El alto tribunal afirmó así en el considerando 5 de Fallos: 322:2399 que *...a la laz de la práctica actual seguida por los estados no es posible afirmar la existencia de un riguroso paralelismo entre la inmunidad de jurisdicción y la inmunidad de ejecución como norma de derecho internacional general, pues no hay prueba de práctica uniforme ni convicción juridica de su obligatoriedad... ". 
aceptación de una inmunidad de ejecución restringida sujeta a la expresa renuncia por parte del Estado extranjero contra el cual se pretende la ejecución ${ }^{148}$ o la acreditación de que el bien a ejecutar se encuentra afectado a una actividad iure gestionis ${ }^{149}$.

\section{De este modo, nuestra Corte parece enrolarse en la visión predominante en el derecho comparado en función de la cual se postula una inmunidad de ejecución relativa, distinguiendo entre bienes afectados a fines comerciales y bienes afectados a fines gubernamentales o públicos ${ }^{150}$.}

148. Observó la Corte en el considerando 7 del fallo mencionado que "... la demandada expresa que los fondos embargados le han sido asignados por el Estado eslovaco para cubrir los costos y gastos necesarios para el cumplimiento de los fines oficiales de la representación diplomática. Alega que no ha rentanciado a la inmunidad de ejecución y que en virtud de lo dispuesto en el art. 32.4 de la Convención de Viena sobre Relaciones Diplomáticas es necesaria una nueva renuncia al respecto (fs. 326/327). Tal afimación denota que el Estado acreditante se ha negado expresamente a la posibilidad de ser sometido a medidas coercitivas".

149. Señaló asi en el considerando 8 "que en las circunstancias del caso, no se ha acreditado que la cuenta bancaria objeto de embargo tenga un destino diferente del que afirma la República Eslovaca, esto es, el de solventar los gastos ordinarios de su embajada en el pais. No se ha acreditado que esa cuenta haya sido abierta con especifico destino a pagar obligaciones originadas en actividades iuris gestionis ni que lo fuera para el pago de obligaciones como las que han dado lugar al litigio, ni que hubiera sido destinada al depósito y extracción de fondos para pagar créditos documentarios o cualquier otro modo de financiamiento de actividades iure gestioni".

150. En esta última categoria, existe una especie de bienes a los cuales las legislaciones nacionales y el derecho internacional proveen una protección especial. Son los casos de la propiedad diplomática, militar y, en cierta medida, de los bancos centrales. Asi, por ejemplo, la propiedad diplomática no sólo encuentra protección en las diversas legislaciones nacionales -como la de los Estados Unidos (artículo 1610(a)(4)(b) de la Foreign Sovereign Immunities Act de 1976) y el Reino Unido (articulo 16(1) de la State Immunity Act de 1978)- sino en tratados internacionales como la Convención de Viena sobre Relaciones Diplomáticas de 1961 y la Convención de las Naciones Unidas sobre las inmunidades jurisdiccionales de los Estados y de sus bienes. Si bien la mayoría de las legislaciones -entre otras, la legislación de los Estados Unidos, el Reino Unido, Australia y Canadá- así como la reciente convención de las Naciones Unidas contemplan ia renuncia del Estado como un supuesto de excepcjón a la inmunidad de ejecución, no existe una posición uniforme en relación a los requisitos que deben observarse y sobre los bienes que debe considerarse que ella recae-destinados a fines comerciales, gubernamentales 0 , incluso, aquellos que gozan de especial protección. Al respecto, la Convención de las Naciones Unidas sobre las inmunidades jurisdiccionales de los Estados y de sus bienes enumera en su articulo 21 clases especiales de bienes que no pueden ser considerados afectados a fines que no sean un servicio público no cometcial, sin perjuicio de su ejecución cuando medie consentimiento del Estado o hayan sido asignados o destinados para la satisfacción específica de la demanda efectuada. La Comisión de Derecho Intemacional en su informe sobre la labor realizada en su $43^{\circ}$ petíodo de sesiones (Ver Documentos Oficiales de la Asamblea General, cuadragésimo sexto periodo de sesiones, Suplemento No. $10(\mathrm{~A} / 46 / 10)$ ) se ocupó de aclarar que "una renuncia generalo una renuncia respecto de todos los bienes en el territorio del Estado del foro, sin mencionar ninguna de las categorias concretas, no bastaria para permitir la adopción de medidas coercitivas contra los bie-nes de las categorias mencionadas en el párrafo I [del artículo 21 del texto definitivo adoptada en diciembre de 2004 por la Asamblea General -bienes afectados a funciones diplomáticas, militares, pertenecientes al banco central, que formen parte del patrimonio cultural del Estado o de sus archi- 
En la práctica, la ejecución de un laudo en el territorio de otros Estados dependerá necesariamente de la visión de los tribunales locales respecto al alcance de la inmunidad de ejecución. En esos casos, quien pretenda la ejecución forzosa deberá acreditar que los bienes objeto de ella no se encuentran alcanzados por la inmunidad y ello no resultará, en general, tarea sencilla ${ }^{151}$.

\section{Palabras finales}

Hemos intentado abordar en estas líneas algunos aspectos que, si bien demuestran la existencia de importantes puntos de contacto entre el arbitraje que involucra al Estado y los particulares y aquél que se suscita únicamente entre estos últimos, también ratifican sus diferencias.

Razones de tiempo y espacio nos impiden profundizar aún más sobre los aspectos tratados o abordar otros temas relevantes como aquellos relacionados con la experiencia en el derecho de la integración, la arbitrabilidad objetiva, la diferencia entre representación y arbitrabilidad subjetiva, la aplicación de la teoría de la apariencia en relación con el consentimiento a arbitraje,

vos, y aquéllos que formen parte de una exposición de objetos de interés cientifico, cultural o histórico]". Ver Documentos Oficiales de la Asamblea General, cuadragésimo sexto periodo de sesiones, Suplemento No. $10(\mathrm{~A} / 46 / 10)$, pp. 155-156. En línea similar, el articulo 13(3) de la State immunity Act de 1978 del Reino Unido autoriza la renuncia en terminos amplios o restringidos y, a la luz de una interpretación armónica de las normas se desprende que, de no limitarse a bienes de carácter comercial, la renuncia debe entenderse extendida a bienes afectados a fines gubernamentales. Sin embargo, la tenuncia en términos generales parece no extenderse a bienes especialmente protegidos (diplomáticos y militares). Ver articulo 16(l) de la State Immunity Act de 1978. Por su parte, el articulo 1610(a) de la Foreign Sovereign Immunities Act de 1976 de los Estados Unidos circunscribe, en principio, la renuncia a la inmunidad de ejecución a los bienes utilizados para actividades comercjales. A este respecto, en líneas generales destaca Schreuer que (i) las renuncias generales a la inmunidad de ejecución deben, en principio, interpretarse extensivas a la propiedad de carácter no comercial; (ii) los bienes especialmente protegidos gozan de una presunción de inmunidad aún en caso de una renuncia general a ella; y (iii) dicha presunción puede super dicha presunción puede superarse, particularmente en relación con la propiedad de los bancos centrales, mediante una renuncia expresa que mencione especificamente esa propiedad. Ver Schreuer, "The ICSID Convention ...", ob. cit. en nota 124 , pp. 1170-1171.

151. La experiencia indica, por el contrario que, en el mayor número de los supuestos, los Estados consiguen justificar que los bienes pertenecen a sus representaciones diplomáticas, a su banco central, forman parte de su patrimonio cultural o se encuentran afectados a cualquier otro fin gubernamental. 
la inmunidad de jurisdicción, el rol del interés público y las prerrogativas estatales en el procedimiento arbitral, la relevancia del derecho del Estado parte -en particular, sus normas de policía y de orden público- frente a la aplicación de una legislación diferente al fondo de la controversia, la confidencialidad de los procedimientos frente al principio de publicidad de los actos de gobierno, la posibilidad de presentaciones de terceras partes en el procedimiento en calidad de amicus curiae o la potestad de los árbitros para declarar la inconstitucionalidad de normas.

El presente trabajo debe, en consecuencia, ser considerado únicamente como una aproximación a un tema que, por su creciente importancia, merece sin lugar a dudas una mayor atención.

Sólo el tiempo dirá si esa atención da lugar a una creciente compatibilización de nuestro derecho interno con las tendencias predominantes en el derecho comparado o, por el contrario, si como ocurre todavía en algunos aspectos, el derecho argentino mantiene en esta materia sus particularidades. 